\title{
REVIEW
}

UDC 352.4

doi: https://doi.org/10.15407/ubj90.04.005

\section{PATHWAYS AND MECHANISMS OF TRANSMEMBRANE CALCIUM IONS EXCHANGE IN THE CELL NUCLEUS}

\author{
T. O. VEKLICH, YU. V. NIKONISHYNA, S. O. KOSTERIN
}

Palladin Institute of Biochemistry, National Academy Sciences of Ukraine, Kyiv; e-mail: veklich@biochem.kiev.ua

\begin{abstract}
A variety of nuclear calcium functions includes regulations of gene transcription and permeability of nuclear pore complexes, activation of numerous enzymes involved in the apoptosis, and therefore cell fate determination. Thus, the pathways of $\mathrm{Ca}^{2+}$ entry into the nucleus, the interplay between nuclear and cytosolic calcium signals, calcium accumulation in the nuclear depot, extrusion and subsequent destinies are of particular interest. In this review, we systematized literature data and our results about aspects of calcium transport in the cell. We especially concentrated on calcium transport systems and general mechanisms of calcium exchange in the central organelle - the nucleus. We also described the general structure of the cell nucleus, nuclear envelope transporters, and the role of $\mathrm{Ca}^{2+}$ in the nucleus and disturbances of nuclear calcium signaling.
\end{abstract}

K ey words: nucleus, nucleoplasm, nuclear envelope, nuclear transporters, calcium signaling.

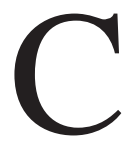

a ions $\left(\mathrm{Ca}^{2+}\right)$ play an important role in regulation of many biochemical, biophysical and physiological processes, acting as cytoplasmic signal transducers that transmit information from the plasma membrane to intracellular structures [1-7]. Changes in the $\mathrm{Ca}^{2+}$ concentration affect virtually all aspects of cellular life from birth to death. $\mathrm{Ca}^{2+}$ is an essential cellular messenger. $\mathrm{Ca}^{2+}$ signaling pathways coordinate a wide range of cellular processes from fertilization, proliferation, secretion of neurotransmitters and other substances, regulation of activity of different enzymes, muscle contraction, neurotransmission, cell growth to apoptosis or necrosis [8-13]. The mechanisms of $\mathrm{Ca}^{2+}$ exchange in the cytosol, on the one hand, and in the endoplasmic reticulum and mitochondria as calcium depots [14-17], on the other hand, have been well studied. However, there is great interest in the understanding the pathways and effects of changes in the intranuclear $\mathrm{Ca}^{2+}$ concentration, since it has been found that fluctuation in the level of $\mathrm{Ca}^{2+}$ in the nucleoplasm is likely to control the activation of nuclear transcription factors, breakdown of the nuclear membrane during cell division, and apoptosis [18]. Furthermore, $\mathrm{Ca}^{2+}$ transport systems and channels involved in the $\mathrm{Ca}^{2+}$ redistribution within a cell were found to exist in nuclear envelope [19]. The European conference on $\mathrm{Ca}^{2+}$ signaling in the cell nucleus, held in Baia Paraellios, Calabria, Italy in 1997, was a springboard for summarization of existing numerous, sometimes polar theories and experimental data related to transmembrane $\mathrm{Ca}^{2+}$ exchange and $\mathrm{Ca}^{2+}$ signaling in the cell nucleus [20].

Published data on the calcium exchange in the nucleus are contradictory and limited, though it is known that the nuclear envelope contains its own system of signal transduction and generation of secondary messengers, and the nucleus lumen may serve as a $\mathrm{Ca}^{2+}$ depot. Moreover, there is a reason to consider the $\mathrm{Ca}^{2+}$ exchange processes in the nucleus, cytosol, and endoplasmic reticulum as interconnected and integrated processes. All this has generated considerable interest in the nucleus as an equally important player in the processes of intracellular $\mathrm{Ca}^{2+}$ exchange. 


\section{General concepts of the $\mathrm{Ca}^{2+}$ level, localization, and distribution in the cell}

As it was noted earlier, $\mathrm{Ca}^{2+}$ is an important signal messenger; changes in its concentration induced by various factors regulate many cellular functions. Minor changes in cytoplasmic $\mathrm{Ca}^{2+}$ affect enzyme activities, initiate signaling cascades, cause muscle contraction, nerve impulse transmission, or secretion. Hence, there is a strict control of cytoplasmic $\mathrm{Ca}^{2+}$, whose concentration in the resting state of the cell does not exceed 50-300 nM. The main $\mathrm{Ca}^{2+}$ store is the lumen of the endoplasmic reticulum (ER), where the $\mathrm{Ca}^{2+}$ concentration is substantially higher - 100-500 $\mu \mathrm{M}$. $\mathrm{Ca}^{2+}$ release from the ER occurs through two types of channels: ryanodine and $\mathrm{IP}_{3}$-sensitive [21]. Other vital subcellular structures that can accumulate $\mathrm{Ca}^{2+}$ are mitochondria. At rest, the concentration of $\mathrm{Ca}^{2+}$ in mitochondria is not high - about $200 \mathrm{nM}$ [22]. However, due to the close association of mitochondria with the sites of $\mathrm{Ca}^{2+}$ release into the cytosol, the mitochondria serve as a buffer system and can accumulate $\mathrm{Ca}^{2+}$ to a level of $10-100 \mu \mathrm{M}$, whereas the concentration of cytoplasmic $\mathrm{Ca}^{2+}$ can increase to 2-3 $\mu \mathrm{M}$ [23]. The highest cellular $\mathrm{Ca}^{2+}$ concentration was detected in plant vacuoles, where this ion is essential for the balance of organic anions. In some cases, its level in these compartments can reach several mM [24].

The idea that nuclear $\mathrm{Ca}^{2+}$ and cytosolic $\mathrm{Ca}^{2+}$ are regulated independently emerged soon after the development of new technologies (confocal microscopy), which enable to monitor $\mathrm{Ca}^{2+}$ changes in several compartments simultaneously. Electron probe microanalysis [25] allowed comparing the $\mathrm{Ca}^{2+}$ concentrations in different cell compartments of one sample of myocytes. Thus, the $\mathrm{Ca}^{2+}$ concentration in peripheral cytosol was $570 \mu \mathrm{M}$ (this value increased to $840 \mu \mathrm{M}$ upon mechanical stretch); in the central cytosol $-400 \mu \mathrm{M}$ (increased to $840 \mu \mathrm{M}$ ). It is interesting to note that the $\mathrm{Ca}^{2+}$ concentration in the nucleus was $180 \mu \mathrm{M}$ (increased to $300 \mu \mathrm{M}$ ), in the nuclear envelope $-933 \mu \mathrm{M}$ (increased to $1530 \mu \mathrm{M})$. Such results allowed suggesting that the nuclear envelope performs the function of a barrier for $\mathrm{Ca}^{2+}$. Furthermore, high $\mathrm{Ca}^{2+}$ concentration in the lumen of nuclear envelope indicates its high $\mathrm{Ca}^{2+}$ capacity and the ability to store $\mathrm{Ca}^{2+}$ to increase the $\mathrm{Ca}^{2+}$ level in the nucleoplasm. The difference in the increases in $\mathrm{Ca}^{2+}$ concentrations in nucleus and cytoplasm can be explained either by the buffering property of the cytoplasm or by the mechanism of independent regulation of the $\mathrm{Ca}^{2+}$ permeability by the nuclear membrane [26]. According to other data, the $\mathrm{Ca}^{2+}$ concentration in the lumen of the nucleus is close to that in the lumen of the endoplasmic reticulum and in the resting state is found to be 100$300 \mu \mathrm{M}$. The $\mathrm{Ca}^{2+}$ concentration in the nucleoplasm is approximately $100 \mathrm{nM}$ and corresponds to the cytoplasmic level [27].

Using aequorin as a $\mathrm{Ca}^{2+}$ sensor in a cell resting state it was shown that there was no difference between the $\mathrm{Ca}^{2+}$ concentration in the cytoplasm and the nucleus. However, under the influence of $\mathrm{IP}_{3}$, the $\mathrm{Ca}^{2+}$ accumulation in the nucleus and the formation of the $\mathrm{Ca}^{2+}$ gradient between the nucleus and the cytoplasm were observed $[18,28]$. It might occur due to the $\mathrm{Ca}^{2+}$ release from the nuclear envelope through the $\mathrm{IP}_{3}$ channels localized in the inner nuclear membrane. Some signaling events were shown to occur without an increase in the $\mathrm{Ca}^{2+}$ concentration in the cytosol, with an increase in the $\mathrm{Ca}^{2+}$ level in the nucleus solely, in particular, in oocyte during fertilization $[18,29]$. Also, an increase in the cytoplasmic $\mathrm{Ca}^{2+}$ concentration is not necessarily accompanied by an increase in free nuclear $\mathrm{Ca}^{2+}$, particularly when $\mathrm{Ca}^{2+}$ signaling occurs in the cytosol [26]. An increase in the cytoplasmic $\mathrm{Ca}^{2+}$ concentration under the influence of histamine, ATP, and ionomycin did not correlate with an increase in the concentration of nuclear $\mathrm{Ca}^{2+}$. This indicates that in the nucleus there is an independent mechanism for $\mathrm{Ca}^{2+}$ regulation [26]. Thus, $\mathrm{Ca}^{2+}$ was shown to be a specific regulator of nuclear events, acting via $\mathrm{Ca}^{2+}$ binding proteins, such as calmodulin, calreticulin and calpain.

\section{Functional role of $\mathrm{Ca}^{2+}$ in the nucleus}

Changes in the $\mathrm{Ca}^{2+}$ concentration in the nucleus regulate basic nuclear functions, such as gene expression, and activate nuclear transcription factors. In addition, $\mathrm{Ca}^{2+}$ was shown to be involved in the development of apoptosis and a breakdown of the nuclear membrane [18].

$\mathrm{Ca}^{2+}$ is the central ion in many signal transduction cascades. Signaling cascades regulate gene expression through the stimulation of transcription factor translocation from the cytosol into the nucleus, or through translocation or activation of enzymes that regulate the transcription factor activity or the chromatin structure. An increase in the $\mathrm{Ca}^{2+}$ concentration in the nucleus may be not an indispensable factor for such events. However, it is necessary for the 
initiation of gene transcription. For example, $\mathrm{Ca}^{2+}$ activates transcription through nuclear factor of activated T-cells (NFAT). This factor is typically located in the cytosol; however, in response to an increase in the cytoplasmic $\mathrm{Ca}^{2+}$ concentration, it translocates to the nucleus and is dephosphorylated by calcineurin. NFAT translocation to the nucleus occurs in the form of the calcineurin-NFAT complex, so, an increased nucleoplasmic $\mathrm{Ca}^{2+}$ concentration provides this association and, hence, maintains the transcriptional activity of NFAT.

The CREB factor (cAMP response elementbinding protein) is an example of a protein that is regulated by both nuclear and cytoplasmic $\mathrm{Ca}^{2+}$ signals. Studies on neurons showed that depolarization leads to CREB phosphorylation by calmodulindependent kinase 4 , which forms the signal that is necessary but not sufficient for CREB-dependent transcription. It was revealed that the level of the $\mathrm{Ca}^{2+}$-calmodulin complex in the nucleus, which depends on the "history" of activation of NMDA receptors on the presynaptic neuronal membrane, is crucial for the activation of CREB and CRE site of gene promoters that promotes neuronal survival and a long-term neuroprotective effect [30]. In the nucleus, CREB binds additional proteins, and forms a transcriptionally active complex - this event requires an increase in the concentration of nuclear $\mathrm{Ca}^{2+}$. The introduction of $\mathrm{Ca}^{2+}$-buffer into the nucleus terminates CREB-dependent transcription. Moreover, an increase in the $\mathrm{Ca}^{2+}$ level in the nucleus was found to be essential for the activation of CBP (CREBbinding protein), which acts as a CREB co-activator [31].

Another interesting mechanism for the neuroprotective effect of the nuclear $\mathrm{Ca}^{2+}$-calmodulin complex, in addition to CREB activation, is the modulation of the nuclear export of transcriptional co-repressors (SMRT, HDAC) and, as a result, activation of corresponding gene transcription. For example, it is known that the gene of neuroprotective myocyte enhancer factor-2 (MEF2) transcription factor is generally repressed by histone deacetylase 2 (HDAC2), and one of the ways of its activation is $\mathrm{Ca}^{2+}$-calmodulin kinase-dependent HDAC2 export from the nucleus [32, 33]. Nuclear $\mathrm{Ca}^{2+}$-calmodulin signaling is also noteworthy for its role in synaptic plasticity and the processes of long-term memory formation [34]. The genes regulated by nuclear $\mathrm{Ca}^{2+}$ level and involved in memory consolidation include VEGFD, Arc, Dnmt3a2, Homer1, Npas4, and nr4a1 [35].
The expression of two other genes, which encode synaptic cell adhesion molecules and regulate synaptic transmission and neuronal plasticity, also depends on $\mathrm{Ca}^{2+}$ transients in the nucleus. The products of these genes are leucine-rich repeat transmembrane proteins (Lrrtm1 and Lrrtm2), whose peak activity is observed on the day of birth. It should be noted that the promoters of the Lrrtm genes contain the CRE site, and hence, their activation via nuclear $\mathrm{Ca}^{2+}$-calmodulin signaling pathway described above is evident [36].

The activity of the downstream antagonist regulatory element modulator (DREAM) is also known to be regulated by nuclear $\mathrm{Ca}^{2+}$. This protein contains $\mathrm{Ca}^{2+}$-binding EF motifs and is directly regulated by an increase in the nuclear $\mathrm{Ca}^{2+}$ concentration. At the low concentration of $\mathrm{Ca}^{2+}$, DREAM represses the gene transcription by binding to DNA, and with the increased concentration of $\mathrm{Ca}^{2+}$ DREAM dissociates [37, 38].

In the experiments on acinar cells of the pancreas, it was found that an increase in the $\mathrm{Ca}^{2+}$ level in the cytoplasm and nucleoplasm under the influence of some agonists, e.g., cholecystokinin, caused an increase in the expression of immediate early genes (IEG): c-fos, c-jun, and c-myc. Changes in the expression level were observed at the concentration of extracellular $\mathrm{Ca}^{2+} 1 \mathrm{mM}$ and were most pronounced at the concentration of $10 \mathrm{mM}$ [39].

$\mathrm{Ca}^{2+}$ signals formed in the cytoplasm and the nucleoplasm can synergistically control critical cellular events. However, independent nuclear $\mathrm{Ca}^{2+}$ signals can regulate specific nuclear processes. For example, $\mathrm{Ca}^{2+}$ is involved in the regulation of nuclear pore permeability. Reduction of $\mathrm{Ca}^{2+}$ in the nuclear membrane leads to the protein influx through the nuclear pore. It is believed that there is a $\mathrm{Ca}^{2+}$-sensor in the nuclear membrane, that is pore membrane protein gp210 (nucleoporin $210 \mathrm{kDa}$ ), which anchors the nuclear pore proteins. A significant amount of protein is localized in the nuclear pore lumen, where it can respond to changes in the $\mathrm{Ca}^{2+}$ concentration [4042]. A decrease in the $\mathrm{Ca}^{2+}$ concentration under the influence of chelators prevents the energy-dependent import of histones and the energy-dependent transport of dextrin molecules [41, 43].

The localization of $\mathrm{IP}_{3}$ receptors on the nuclear membrane enables the formation of the nuclear-specific $\mathrm{Ca}^{2+}$ signals (even though they are initiated in the cytosol) that might be essential to regulating the gene transcription. Similar channels were discovered 
on cardiomyocytes, and such mechanism, along with periodic fluctuations in the cytosolic $\mathrm{Ca}^{2+}$ level, may be employed in the induction of cardiac hypertrophy [44].

An equally important function of nuclear $\mathrm{Ca}^{2+}$, along with cytosolic $\mathrm{Ca}^{2+}$, is regulation of apoptosis. This role of nuclear $\mathrm{Ca}^{2+}$ seems obvious, given the localization in the nucleus of the $\mathrm{Ca}^{2+}$-dependent endonucleases and proteases involved in chromatin fragmentation and protein digestion during apoptosis [45]. It was shown that an increase in the $\mathrm{Ca}^{2+}$ level in the nucleoplasm correlates with the development of apoptosis as a result of the activation of these enzymes, whereas $\mathrm{Ca}^{2+}$ release from the nucleus is accompanied by elevated activity of anti-apoptotic Bcl-2 proteins [20].

Thus, changes in the nuclear $\mathrm{Ca}^{2+}$ concentration trigger activation of transcription factors (in particular their phosphorylation/dephosphorylation), their dissociation or binding to the corresponding DNA site, changes in the localization of the transcriptional repressors. However, the functional role of $\mathrm{Ca}^{2+}$ in the nucleus is not confined to the effect on gene transcription that generates increasing interest in the processes of ion exchange in the nucleus.

\section{The functional organization of the cell nucleus}

For a long time, the structural complexity of the nucleus was underestimated, and the nucleus was seen only as a repository of genetic information packed in chromatin fibrils that are freely distributed in the amorphous nucleoplasm. Since the nucleus does not contain a system of internal membranes (as in the cytoplasm), its compartmentalization was not considered at the time [46]. However, the development of electron microscopy and immunohistochemistry enabled to visualize distinct nuclear compartments $[47,48]$. Thus, the discovery of different subnuclear compartments at the beginning of the 20th century can be considered the renaissance in research of nucleus hyperfine structure. Thus, in 1903, the neuroscientist Santiago Ramon Cajal first described the small argentophilic bodies associated with the nucleolus, which he named nucleolar accessory bodies, or coiled bodies [47]. In 1999, Joseph Gall renamed these structures Cajal bodies in honor of the discoverer [47, 49]. In 1910 Cajal gave a detailed description of another nuclear domain - interchromatin compartment - called nuclear speckles [48]. The existence of nucleolus within the nucleus was reported in 1835. The monumental monograph published by Montgomery (1898) with remarkable 346 drawings of nuclei and nucleoli from different cell types is convincing evidence of existence of a large dense structure within the nucleus $[48,50]$. However, details of the nucleolus structure and functions were revealed much later with the development of electron microscopy techniques.

According to modern views, a part of the nucleus, which is characterized by a subset of macromolecules and specialized functions, is considered a nuclear compartment [51, 47]. The nuclear compartments include nucleolus, chromosome territories, interchromatin domain, transcriptional sites and nuclear bodies (Cajal body, PML) [46, 47, 51-53] (Fig. 1).

The nucleolus, the most noticeable nuclear structure, is assembled around the rRNA genes and formed by ribonucleoproteins. However, the function of the nucleolus is not just restricted to the synthesis of rRNA and biogenesis of the ribosomes [48]. According to $\mathrm{C}$. $\mathrm{H}$. Waddington, the researcher of the nucleolus, the nucleolus should not be considered a relatively simple organelle with a single function, comparable to a particular part of an automobile. It is rather a whole production line than a single machine tool. Thus, the nucleolus is the site for rRNA processing with the involvement of small nucleolar RNAs and is also the site of formation of signal recognition particle RNA [48, 54]. The nucleolus is characterized by much higher protein/RNA ratio than the mature ribosome. It also contains proteins involved in DNA replication and repair, as well as cell cycle regulators [55]. For instance, nucleostemin, a protein which shuttles between the nucleolus and nucleoplasm, is found inside the nucleolus. While transporting to the nucleoplasm, it binds and inactivates p53 [56]. Besides, there is a small p53 pool within the nucleolus, which interacts with molecular partners other than those with which it usually forms the complex in the nucleoplasm [48].

\section{Ion exchange systems in the nuclear membrane}

Recent reported data have indicated that the nuclear envelope is involved in a wide variety of cellular processes ranged from the transport of macromolecules through nuclear pore complexes to signal transduction, cell cycle regulation, and regulation of embryonic and postembryonic development [35, $57,58]$. Despite the obvious role of the nuclear en- 


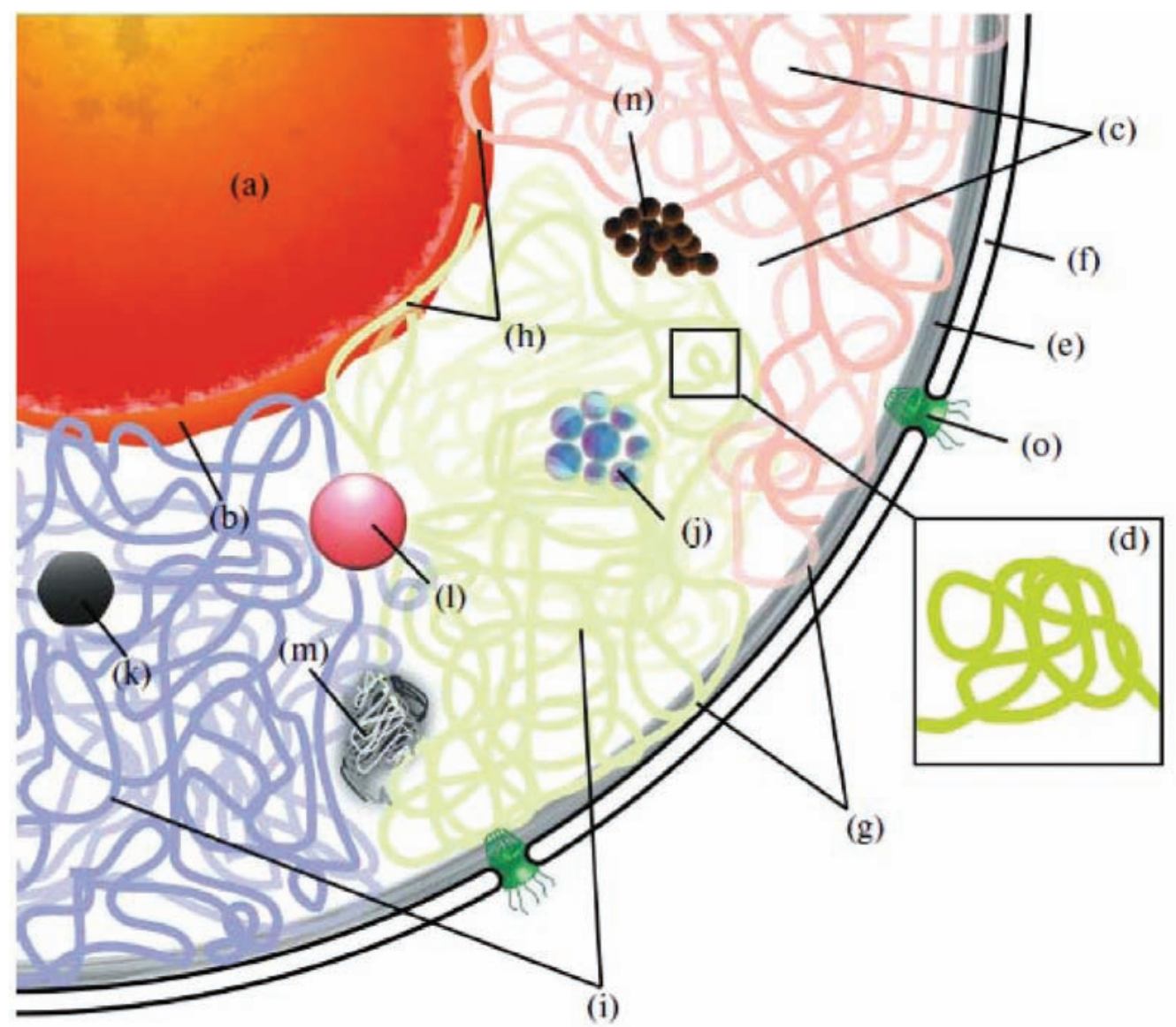

Fig. 1. Structure of the cell nucleus with the indication of all known nuclear compartments [51]: (a) - nucleolus, (b) - perinuclear space, (c) - interchromatin domain, (d) - topologically associated domain, (e) - lamina, $(f)$ - nuclear envelope, $(g)$ - lamina associated domains, $(h)$ - nucleolus associated domains, (i) - chromosome territories, $(j)$ - Polycomb body, $(k)$ - insulator body, (l) - promyelocytic leukemia oncoprotein body (PML body), (m) - Cajal body, (n) - nuclear speckles, (o) - nuclear pore complex

velope in the cell functioning, some aspects, including the electrophysiological properties of the double membrane, remain poorly understood. The reasons for the limited knowledge about this essential nuclear structure are the following. First, researchers for a long time focused on the study of nuclear envelope proteins involved in the transport of macromolecules and proteins associated with chromatin [57]. Second, gaps in the understanding of "nuclear electrophysiology" are associated with difficulties in purifying of the nuclear envelope from the endoplasmic reticulum membranes. In intact cells and isolated nuclei, the inner nuclear membrane is inaccessible for patch clamp pipette that complicates electrophysiological studies. In addition, methods for separating the inner nuclear membrane from the outer one have not been developed yet [57].
The features of the nuclear-cytoplasmic $\mathrm{Ca}^{2+}$ transport may account for the structural peculiarities of the nuclear envelope, which has an inner and outer membranes with the perinuclear space between them. The nuclear envelope is usually $30-50 \mathrm{~nm}$ wide in somatic cells. The inner and outer nuclear membranes differ in structure and function. The outer membrane is continuous with the endoplasmic reticulum membrane, so the perinuclear space is connected with the lumen of the endoplasmic reticulum [48, 57]. In the link sites of inner and outer membranes, the nuclear envelope has many nuclear pore complexes that are supramolecular structures responsible for preserving the integrity of the double nuclear membrane and for the transport of molecules between the cytoplasm and the nucleoplasm [19, 59, 60]. 
The most well-studied nuclear transport structures are nuclear pore complexes (NPC) that cross the double nuclear membrane. The molecular mass of the NPC is about $10^{8} \mathrm{Da}$; the diameter is about $120 \mathrm{~nm}$. A three-dimensional analysis of the NPC structure revealed that it has octagonal rotational symmetry around large central channel (diameter of 40-70 nm) surrounded by eight small peripheral channels (diameter of $10 \mathrm{~nm}$ (in the open state)) [61, 62]. Interestingly, this multi-protein complex is involved in the nuclear-cytoplasmic transport of not only macromolecules (RNA, proteins) but also ions [37]. However, the question remains: whether this transport is regulated, or it occurs via passive ion diffusion? By recently, researchers who sought to establish whether the NPC provides for constitutive ion conductivity, or it remains, for some time, in a closed state, obtained discrepant results depending on the electrophysiological approach [57, 63, 64]. It is believed that the NPCs transport ions steadily (at least through peripheral channels if the central channel is partially blocked [57]), but their conductivity can vary depending on the effect of such factors as the concentrations of $\mathrm{Ca}^{2+}$ and ATP [65]. The NPC is likely to serve as a mechanism for a delay in equilibration between the cytoplasmic and the nucleoplasmic $\mathrm{Ca}^{2+}$ concentration.

Early electron microscopic studies revealed that the NPC is formed by about 100 proteins [57]. Later, the proteomic analysis of yeast and mammalian NPCs, however, disproved the existence of such a large number of proteins, and demonstrated that the NPC contains approximately 30 different core proteins that have numerous copies [66]. It is interesting to note that the NPCs from all eukaryotes have common structure indicating the conservatism of the nuclear pore components organisation. Electron microscopy analysis established that the NPC has an octagonal symmetry and spoke wheelshaped architecture. The core structure, embedded in the nuclear envelope, is formed by the nucleoporin proteins (Nup) and bounded by cytoplasmic and nuclear rings with attached filaments whose ends are attached to the terminal ring [20,37]. Nup proteins play a crucial role in the formation of the central channel through which active molecule transport occurs. The permeability limit of this transport machinery was determined by studying the transport of fluorescently labeled dextrans of different sizes and gold particles. It was reported that molecules larger than $40 \mathrm{kD}$ and $5 \mathrm{~nm}$ could not permeate the
NPC $[48,67]$. So, the molecules of water, small metabolites, and metal ions can freely diffuse through a nuclear pore. The transport of macromolecules $(>40 \mathrm{kDa}$ ) through the NPC is highly selective, since only specific molecules that contain nuclear transport signals, namely nuclear export signal (NES) or nuclear localization signal (NLS) can pass across this barrier. It was shown that a cargo up to $39 \mathrm{~nm}$ (tRNA, some proteins, ribosomal subunits, viral particles) can be translocated through the pores either by directly binding to the NPC components or by forming a complex with soluble transport proteins, karyopherins $[48,68]$. The transport of particles with a diameter of approximately $50 \mathrm{~nm}$ (mRNA in complex with proteins) is also possible, but it requires a rearrangement of the particle to reduce its diameter [69].

The function of NPC is not only bidirectional transport of molecules. The NPC, namely Nup84, was shown to be involved in anchoring of some telomeres and their length regulation. Deletion of Nup84 led to disruption of DNA repair by non-homologous end joining (NHEJ) [70].

It is important that the nuclear pores also mediate the $\mathrm{Ca}^{2+}$ transport between the nucleoplasm and the cytosol. This transport is likely to be regulated and depends on the $\mathrm{Ca}^{2+}$ concentration in the lumen (details will be discussed below). In response, the $\mathrm{Ca}^{2+}$ level in lumen affects the transport of molecules through nuclear pores [37, 71]. However, there is no consensus yet on the peculiarities of $\mathrm{Ca}^{2+}$ regulation of the nuclear pores conductivity for different molecules.

Taking into account the features of the NPC functioning, it has been suggested that ion transporters must contain the nuclear localization signal (NLS) sequence to be translocated from their synthesis sites to the nucleus and to be incorporated into nuclear membranes. Presently, the entire spectrum of sequences attributed to NLS has not been determined; however, at least two types of nuclear localization sequences are known: pentapeptide KKKRK and NLS formed by two clusters of basic amino acid residues separated by 10 residues [72]. Thus, the presence or absence of certain transport system in the nuclear envelope can be established by its amino acid sequence.

The existence of various ion exchange systems in the nuclear envelope of animal and plant cells was revealed using electrophysiological techniques (in particular, the patch-clamp). Although the localiza- 
tion of all nuclear ion channels and pumps has not been determined yet, it was found that some of them function in the outer nuclear membrane, others in the inner nuclear membrane, and certain transporters are located in both membranes [57, 67, 73].

The only now cloned nuclear transporter is chloride channel-27 (NCC27/CLIC1), which exists in the internal nuclear membrane of plant and some animal cells [66]. NCC27/CLIC1 was determined to contain the nuclear localization signal NLS, formed from two sequences of basic amino acids separated by a fragment of 10 amino acids (which ensures the transport of this protein from the place of its synthesis in the cytosol to the inner nuclear membrane). Given the two-component structure of the chloride channel NLS, Marjori Matzke and colleagues performed a screening of ion transport proteins in Arabidopsis (using the INTERPRO database) for the presence of two-component NLS in their composition to identify potential ion channels and pumps localized in the inner membrane of the plant cell nucleus [57]. Thus, potential-dependent $\mathrm{Cl}^{-}$-, $\mathrm{K}^{+}$-channels, cAMP-dependent ion channels and $\mathrm{Ca}^{2+}$-ATPase were detected in the nuclear envelope. However, the sequence mentioned above was not found in the composition of, e.g., V-type $\mathrm{H}^{+}-$ ATPase [66].

The presence of a two-component NLS sequence does not guarantee that the protein will be exclusively nuclear. Moreover, the INTERPRO database allows identifying only two-component NLS in proteins but not other types of NLS [74]. Thus, the range of existing nuclear transporters is likely to be wider and the use of other methods is required for a thorough study of this issue.

An interesting example of the ion channels functioning in nuclear membrane is the involvement of some nuclear membrane ion channels of legume roots in the generation of $\mathrm{Ca}^{2+}$-spikes, which occur as a result of the interaction of rhizobial symbionts with the roots of these plants. For example, DMI1, CASTOR, and POLLUX are the nuclear membrane cation channels which have higher selectivity to $\mathrm{K}^{+}$ over $\mathrm{Na}^{+}$and $\mathrm{Ca}^{2+}$. Such ionic conductivity of these transporters led to hyperpolarization of the inner nuclear membrane and the $\mathrm{Ca}^{2+}$ release from the lumen into the nucleoplasm. An increase in the $\mathrm{Ca}^{2+}$ concentration in the nucleoplasm might induce the expression of endosymbiotic genes [75, 76].

Proteome analysis, which enables to distinguish nuclear proteins from microsomal membrane proteins, demonstrated that $\mathrm{Ca}^{2+}$ channels, $\mathrm{Zn}^{2+}$ transporters, $\mathrm{Na}^{+} / \mathrm{H}^{+}$exchangers are also localized in the nucleus [57].

It was found, using antiserum to the $\mathrm{N}$ - and C-terminal epitopes of ATP-regulated P2X7 channels, that these transporters exist in the outer nuclear membrane of all hippocampal neurons (whether they are excitatory or inhibitory). Immunoassay electron microscopy data revealed that $\mathrm{P} 2 \mathrm{X} 7$ crosses nuclear membranes, since antiserum labels were detected on the cytoplasmic and nucleoplasmic sides of the nuclear envelope [77]. Binding of ATP to the cytoplasmic site of the receptor induced the activation of a non-selective $\mathrm{Ca}^{2+}$ channel in the nuclear membrane, and, thus, changes in the $\mathrm{Ca}^{2+}$ concentration in the nucleoplasm [77, 78].

Interestingly, these purinergic receptors are concentrated in the presynaptic membranes exclusively of excitatory neurons. However, their content in nuclear membranes is high in both excitatory and inhibitory neurons [77]. Probably, different changes in the nucleoplasm $\mathrm{Ca}^{2+}$ concentration in excitatory and inhibitory neurons under the influence of activated $\mathrm{P} 2 \mathrm{X} 7$ affect in different degree the transcriptional activity of genes involved in neuronal plasticity or affect different neuronal plasticity-related genes in these neurons.

Apart from the potential-dependent $\mathrm{K}^{+}$channels [79], ATP-sensitive $K^{+}$channels $\left(K_{\text {ATP }}\right)$ were also shown to operate in the nuclear membrane (at least in some cells). For example, in the $\beta$-cells of mice pancreatic islet, along with plasma membrane $\mathrm{K}_{\text {ATP}}$, the nuclear $\mathrm{K}_{\text {ATP }}$ was detected by fluorescent dye glibenclamide-BODIPY-FL. The plasma membrane $\mathrm{K}_{\text {ATP }}$ in pancreatic cells is known to be involved in the regulation of insulin secretion from $\beta$-cells: the increase in ATP concentration in these cells, as a result of glucose uptake from blood, leads to the closure of ATP-sensitive $\mathrm{K}^{+}$-channels in the plasma membrane and the $\mathrm{Ca}^{2+}$ influx through potentialdependent $\mathrm{Ca}^{2+}$ channels in response to the plasma membrane depolarization. A further increase in the cytosolic $\mathrm{Ca}^{2+}$ concentration is a prerequisite event for the fusion of insulin-containing secretory vesicles and the insulin secretion from pancreatic $\beta$ cells [80]. The nuclear $\mathrm{K}_{\text {AтP }}$ channels closure, in response to an increase in ATP level, leads to increased nucleoplasmic $\mathrm{Ca}^{2+}$ concentration. The latter, in turn, induces the CREB phosphorylation and expression of the c-Myc transcription factor, which is responsible for cell growth and proliferation [81]. 
From all of those above, it can be concluded that the nuclear membranes contain the following ion exchange systems:

\begin{tabular}{|c|c|}
\hline Inner membrane & Outer membrane \\
\hline NPC & NPC \\
\hline $\begin{array}{l}\text { Voltage-gated } \\
\mathrm{K}^{+} \text {channels (VGKCs) }\end{array}$ & $\begin{array}{l}\text { Voltage-gated } \\
\mathrm{K}^{+} \text {channels (VGKCs) }\end{array}$ \\
\hline $\mathrm{K}_{\mathrm{ATP}}$ ? & $\mathrm{K}_{\mathrm{ATP}}$ ? \\
\hline \multirow[t]{2}{*}{$\mathrm{P} 2 \mathrm{X} 7$} & $\begin{array}{l}\text { P2X7 } \\
\text { NCC27|CLIC1 }\end{array}$ \\
\hline & $\begin{array}{l}\text { Cyclic nucleotide-gated } \\
\text { channels (CNGs) }\end{array}$ \\
\hline $\begin{array}{l}\mathrm{Ca}^{2+} \text { channels: } \\
\text { - IP3R } \\
\text { - RyR } \\
\text { - IP4R }\end{array}$ & $\begin{array}{l}\mathrm{Ca}^{2+} \text { channels: } \\
\text { - IP3R } \\
\text { - RyR } \\
\text { - NADPR }\end{array}$ \\
\hline $\mathrm{Ca}^{2+}$-ATPase? & $\mathrm{Na}^{+} / \mathrm{H}^{+}$exchanger? \\
\hline \multirow[t]{2}{*}{$\mathrm{Na}^{+} / \mathrm{H}^{+}$exchanger? } & $\begin{array}{l}\mathrm{Na}^{+} / \mathrm{Ca}^{2+} \text { exchanger } \\
(\mathrm{NCX})\end{array}$ \\
\hline & $\mathrm{Na}^{+}, \mathrm{K}^{+}$-ATPase \\
\hline
\end{tabular}

A general scheme for the localization of known nuclear transporters in a nuclear envelope is presented in Fig. 2 [57]. Some of the nuclear envelope transporters ( $40 \%$ of the total amount) are present in the membranes of other organelles. Thus, in addition to specific functions, a nuclear membrane, to some extent, "recapitulates" the functions of some cellular organelles [57].

\section{ATP-hydrolases and nuclear membrane}

Nuclear membrane has been long known to have ATPase activity. ATP analog S-dinitrophenyl6-mercaptopurine riboside triphosphate was found to inhibit nuclear ATPase activity. The inhibition was observed only on the isolated membrane in the presence of DNase but not on the whole nuclei and heparin vesicles that indicates that ATPases are localized on the inner side of the nuclear envelope. It was believed that their biological role is the involvement in RNA transport processes, since the ATPase activity increases in the RNA preparations, and the mRNA-protein complexes are transported from the nucleus more efficiently in the presence of ATP [82].

Some studies have demonstrated a functioning $\mathrm{Na}^{+}, \mathrm{K}^{+}$-ATPase in the nuclear envelope (for example, in hepatocyte nuclei [83], in HEK293 cell nuclei [84]), where this pump provides a driving force for $\mathrm{Ca}^{2+}$ transport into the nuclear lumen via $\mathrm{Na}^{+}$/
$\mathrm{Ca}^{2+}$ exchanger (NCX) (similar to the "cooperation" of $\mathrm{Na}^{+}, \mathrm{K}^{+}$-ATPase and $\mathrm{NCX}$ in the plasma membrane). Thus, the presence of $\mathrm{Na}^{+}, \mathrm{K}^{+}$-ATPase in isolated HEK 293 cell nuclei was confirmed by immunoblotting (using antibodies to the $\alpha$-subunit of the protein), enzyme assay (determination of the ouabain-sensitive ATPase activity), and immunocytochemistry. In the latter case, to confirm the presence of $\mathrm{Na}^{+}, \mathrm{K}^{+}$-ATPase in the nuclear envelope (and not only in nuclear preparations with contaminants of the endoplasmic reticulum and fragments of plasma membranes) the authors incubated isolated nuclei with anti- $\mathrm{Na}^{+}, \mathrm{K}^{+}$-ATPase $\alpha$-subunits on the background of staining with antibodies against the NPC protein. Overlap of the signals indicated the functioning of both proteins in the nuclear envelope [84].

A question concerning the localization of $\mathrm{Na}^{+}, \mathrm{K}^{+}$-ATPase in the nuclear envelope (inner, outer or both membranes) drew much attention. To answer this question, a method for isolation the nuclear outer and inner membranes [85, 86], followed by proteins separation of both membranes by immunoblotting (using antibodies to the $\mathrm{Na}^{+}, \mathrm{K}^{+}$-ATPase $\beta$-subunit) was used. The results obtained by Galva revealed that this enzyme is present exclusively in the inner nuclear membrane [84].

There are data demonstrating the localization of V-type $\mathrm{H}^{+}$-ATPases (V-ATPase) in the outer and inner nuclear membranes. V-ATPase was suggested to generate $\mathrm{H}^{+}$-gradients, which mediate the protoncoupled transport of substrate [87]. Moreover, the corroboration that V-ATPase functionally operates in the nuclear envelope will make researchers revise the accepted ideas about the regulation of nuclear $\mathrm{pH}$ : probably, the transport of protons through the nuclear pore complexes is restricted, and V-ATPase plays a crucial role in maintaining the nuclear $\mathrm{pH}$.

Apart from $\mathrm{Na}^{+}, \mathrm{K}^{+}$-ATPases and $\mathrm{H}^{+}$-ATPases, nuclear envelope also contains $\mathrm{Ca}^{2+}$-ATPases. The significance of $\mathrm{Ca}^{2+}$-ATPase as a system of active $\mathrm{Ca}^{2+}$ transport into the nuclear lumen was evidenced by the findings that inhibition of $\mathrm{Ca}^{2+}$-ATPase impede the histones import through the nuclear pore, which conductivity depends on the $\mathrm{Ca}^{2+}$ level in the nuclear store [71].

\section{VI. $\mathrm{Ca}^{2+}$ transport systems in the nucleus}

Various research sources demonstrated the existence of both transport systems in the nuclear envelope $-\mathrm{Ca}^{2+}$ release system from the lumen into cytosol or nucleoplasm via $\mathrm{Ca}^{2+}$ channels and $\mathrm{Ca}^{2+}$ flux into the lumen $\left(\mathrm{Ca}^{2+}\right.$-ATPase, NCX) $[57,67,88]$. 


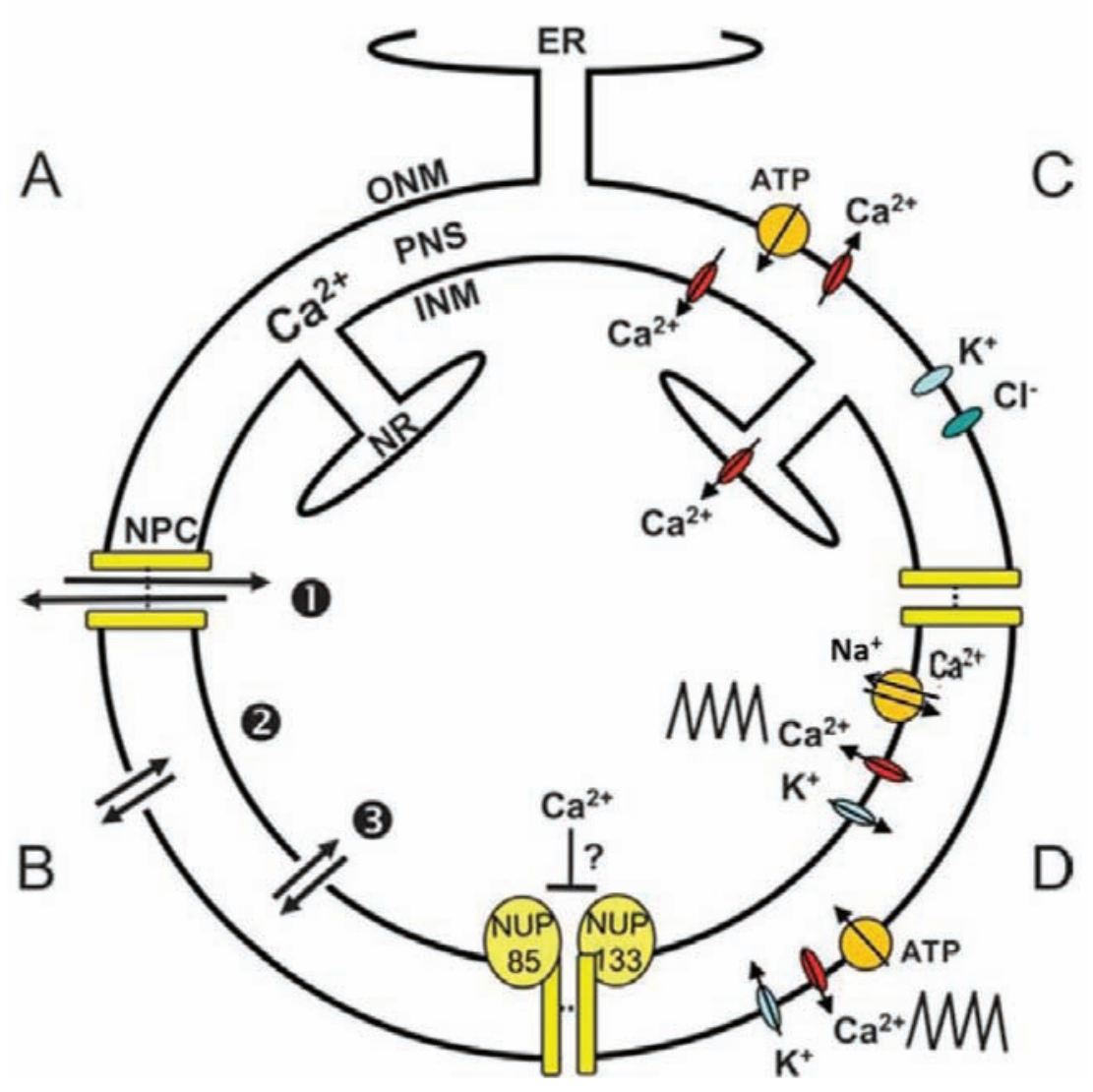

Fig. 2. Ion exchange systems in the nuclear envelope [57]. (A) - structure of the nuclear envelope: ONM outer nuclear membrane, INM - inner nuclear membrane, PNS - perinuclear space, ER-endoplasmic reticulum, NR - nucleoplasmic reticulum, NPC - nuclear pore complex. (B) - three routes of ion transport across the nuclear envelope: 1 - across the NPC, 2 - across the ONM, 3 -across the INM. (C-D) - ion transport systems in the nuclear envelope: active transport systems depicted as the yellow spheres

$\mathrm{Ca}^{2+}$ release occurs via ligand-controlled $\mathrm{Ca}^{2+}$ channels of both nuclear membranes - outer (release of $\mathrm{Ca}^{2+}$ from the lumen into cytosol) and inner (release of $\mathrm{Ca}^{2+}$ from the lumen into nucleoplasm) [20]. Both membranes contain ryanodine (RyRs) and $\mathrm{IP}_{3}$ receptors. NAADPRs, as well as an enzyme for the synthesis of cADP-ribose and nicotinic acid adenine dinucleotide phosphate (NAADP) are localized in the inner membrane, while other $\mathrm{Ca}^{2+}$ channels, which operate in plasma membrane, endoplasmic reticulum or lysosomes (e.g., TRP), were not found in the nuclear envelope [37, 38].

$\mathrm{IP}_{3}$-regulated $\mathrm{Ca}^{2+}$ channels. According to the published data, the leading role in the $\mathrm{Ca}^{2+}$ release from the nucleus is played by $\mathrm{IP}_{3}$-regulated $\mathrm{Ca}^{2+}$ channels located in both nuclear membranes. Although the proportion of the IP ${ }_{3}$ channels on the inner membrane is only $1 \%$, their functioning provides an essential part of the $\mathrm{Ca}^{2+}$ release into the nucleo- plasm [37]. Evidence in support of the existence of functionally active $\mathrm{IP}_{3}$ receptors in an isolated nucleus was found before the European Conference in Calabria, in 1990 [89].

Although $\mathrm{IP}_{3}$-regulated $\mathrm{Ca}^{2+}$ channels have been found on the membranes of Golgi apparatus, lysosomes, endosomes (what would be expected since these compartments are formed during biogenesis of endoplasmic reticulum membranes), the significance of these channels as a system for $\mathrm{Ca}^{2+}$ transport from the store into the cytosol is most evident for the endoplasmic reticulum. A typical $\mathrm{IP}_{3}$ receptor has tertiary structure and consists of three parts: N-terminal ligand-binding domain (on the cytosolic or nucleoplasmic side), a regulatory domain in the central part of the molecule (binding sites for $\mathrm{Ca}$, ATP, chromogranin B, protein kinase phosphorylation) and C-terminal domain, which is $\mathrm{Ca}^{2+}$ channel $[76,90]$. It is important to note that even 
a high level of $\mathrm{IP}_{3}$ is not enough to trigger channel activation: the combined effect of $\mathrm{IP}_{3}$ and $\mathrm{Ca}^{2+}$ on the receptor is necessary. The dependence of the $\mathrm{IP}_{3}{ }^{-}$ induced release of $\mathrm{Ca}^{2+}$ into the cytosol on $\left[\mathrm{Ca}^{2+}\right]$ has a bell-shaped form with the optimum cytosolic $\mathrm{Ca}^{2+}$ concentration of $600 \mathrm{nM}$, that is likely to be a protective mechanism and prevent an excessive increase in the cytosolic $\mathrm{Ca}^{2+}$ level [91].

Ryanodine receptors (RyRs). Unlike in skeletal muscle cells, RyRs in the membranes of the sarcoplasmic reticulum and nucleus in smooth muscle cells, do not directly contact the L-type voltage-gated $\mathrm{Ca}^{2+}$ channels (VGCCs) in plasma membranes. Therefore, for their activation in smooth muscle cells, just the changes in the VGCCs conformation are insufficient, $\mathrm{Ca}$ ions that enter through the VGCCs or IP Rs into the cytosol and bind to the cytosolic site of RyRs are required. The affinity of the ion channels for $\mathrm{Ca}^{2+}$ increases when they bind endogenous ligand (cyclic ADP-ribose). However, the affinity for $\mathrm{Ca}^{2+}$ can also change under the influence of other factors $\left(\mathrm{Ca}^{2+}, \mathrm{Mg}^{2+}, \mathrm{H}^{+}, \mathrm{ATP}\right.$, calmodulin, protein kinase $\mathrm{C}$ and $\mathrm{A}$, methylxanthines (e.g., caffeine)) [90, 92].

In smooth muscle cells, the release of $\mathrm{Ca}^{2+}$ from the RyRs cluster increases the local $\mathrm{Ca}^{2+}$ concentration. This event is called a calcium spark. Calcium sparks can modulate the plasma membrane excitability causing hyperpolarization by activation of $\mathrm{Ca}^{2+}$-activated $\mathrm{K}^{+}$channels of small and large conductance (SK channels and BK channels, respectively) or depolarization by activation of $\mathrm{Ca}^{2+}$-activated Cl channels [90].

NAADPR. The nicotinic acid adenine dinucleotide phosphate (NAADP) receptors are found mainly in the endolysosomal compartments, where the high proton concentration, for the NAADP synthesis from $\mathrm{NADP}^{+}$in the presence of ADP-ribosyl cyclase (CD38), is maintained [93]. The NAADPactivated $\mathrm{Ca}^{2+}$ release from these compartments occurs through NAADPR, called two-pore channels (TPC2). The relatively small amount of $\mathrm{Ca}^{2+}$ released from endolysosomes through these channels can induce global $\mathrm{Ca}^{2+}$ waves due to stimulation of Ca-induced $\mathrm{Ca}^{2+}$ release from the stores via RyRs [94, 95]. Moreover, in some cases, NAADP itself may act as a RyRs activator.

Research on isolated nuclei of pancreatic acinar cells demonstrated that active NAADPRs also exist in the nuclear envelope [96]. These transporters are inhibited by ruthenium red and ryanodine (inhibitors of RyRs) but not caffeine [67]. Remarkably, these receptors are specific exclusively to NAADP and cannot be activated by NAADP analogs, $\beta$-NADP and NAAD [97]. However, the functional role of the NAADP receptors in the nucleus still requires further study. Thus, taking into consideration the location of calcium channels in the nuclear envelope, $\mathrm{Ca}^{2+}$ releases from the lumen in both directions: into the cytosol (via $\mathrm{IP}_{3}$-mediated $\mathrm{Ca}^{2+}$ channels and RyRs) and into the nucleoplasm (via activation of the $\mathrm{IP}_{3}$-mediated $\mathrm{Ca}^{2+}$ channels, RyRs and NAADPRs). However, what route is preferred at the molecular level - is a question for further investigation.

$\mathrm{Ca}^{2+}$ is accumulated in the nucleus depot via the $\mathrm{Ca}^{2+}$-ATPase and $\mathrm{Na}^{+} / \mathrm{Ca}^{2+}$-exchanger - $\mathrm{Ca}^{2+}$ extrusion systems from the cytosol and nucleoplasm. Another mechanism for $\mathrm{Ca}^{2+}$ transport to the nuclear lumen, proposed in 1993, is $\mathrm{IP}_{4}$ (inositol1,3,4,5-tetrakisphosphate)-mediated $\mathrm{Ca}^{2+}$ uptake, which remains puzzling [98, 99]. It was assumed that the concentration of free $\mathrm{Ca}^{2+}$ in the cytosol/ nucleoplasm is the main factor in the "choice" between ATP- and $\mathrm{IP}_{4}$-mediated $\mathrm{Ca}^{2+}$ transport into the depot: the $\mathrm{IP}_{4}$-mediated mechanism is triggered at the $\mathrm{Ca}^{2+}$ concentration $>1 \mu \mathrm{M}$ [98]. It is interesting that the "nuclear" functions of $\mathrm{IP}_{4}$ and other inositol polyphosphates include not only the regulation of $\mathrm{Ca}^{2+}$ signaling but also gene transcription, chromatin remodeling, DNA repair, RNA export, and mRNA and tRNA editing [100, 101].

A summary scheme of the pathways that regulate the $\mathrm{Ca}^{2+}$ concentration in the nucleus is presented in Fig. 3 [37]. Inositol-1,4,5-triphosphate ( $\left.\mathrm{IP}_{3}\right)$ as a ligand of $\mathrm{IP}_{3}$-regulated $\mathrm{Ca}^{2+}$ channels can be formed from PI-4,5-P2, the component of plasma or nuclear membranes, since the nuclear envelope has its own pool of PI-4,5-P2 and phospholipase C $\beta$. Another mechanism of $\mathrm{Ca}^{2+}$ mobilization involves the translocation of ligand-stimulated phospholipase $\mathrm{C}$ from the plasma membrane to the nuclear membrane. In addition, $\mathrm{Ca}^{2+}$ can diffuse in and out the nucleus through the NPC. The supposed mechanism (although it has not been shown in all studies) is also presented in this scheme. This pathway implies that the hormone-receptor complex is translocated into the nucleus and activates nuclear phospholipase $\mathrm{C}$ and synthesis of $\mathrm{IP}_{3}$. In the nucleus $\mathrm{IP}_{3}$ serves as a substrate for the synthesis of other inositol polyphosphates, which modulate gene expression.

$\mathrm{Ca}^{2+}$-ATPase. It is believed that $\mathrm{Ca}^{2+}$ accumulation in the perinuclear store occurs as a result of 


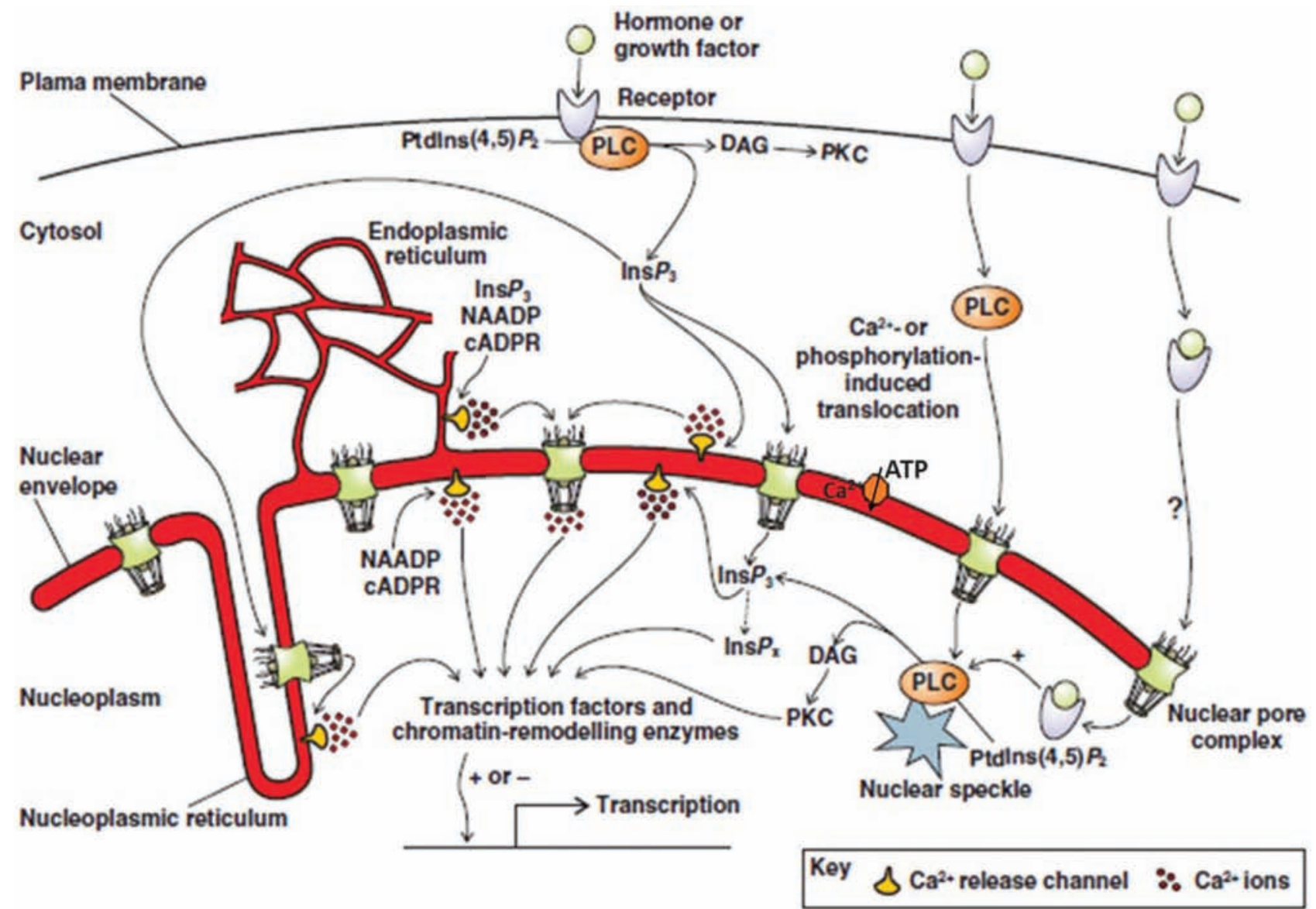

Fig. 3. $\mathrm{Ca}^{2+}$ signaling pathways and transport in the nucleus [37]

the activation of nuclear $\mathrm{Ca}^{2+}$-ATPases [85, 102]. The $\mathrm{Ca}^{2+}$-ATPase activity and ATP-dependent $\mathrm{Ca}^{2+}$ accumulation were for the first time shown in isolated hepatocyte nuclei using a $\mathrm{Ca}^{2+}$-sensitive probe Indo-1. Addition of ATP to the incubation medium resulted in an increase in the $\mathrm{Ca}^{2+}$ concentration in hepatocyte nuclei from 100 to 540-800 nM. Removal of ATP from the medium led to a passive release of accumulated $\mathrm{Ca}^{2+}$ along its concentration gradient [103]. The subnuclear localization of $\mathrm{Ca}^{2+}$-ATPase has not been completely established. Most researchers believe that the enzyme is located only on the outer nuclear membrane [104, 85]. $\mathrm{Ca}^{2+}$-ATPase has been recently shown to exist in the nuclear envelope of osteoblasts [105], neurons [106], oocytes [107] and lymphocyte [108].

Structures of nuclear $\mathrm{Ca}^{2+}$-ATPase and sarcoplasmic reticulum $\mathrm{Ca}^{2+}$-ATPase are similar that was confirmed by comparative $\mathrm{Ca}^{2+}$-ATPase proteolysis and its reaction with antibodies. However, the nuclear $\mathrm{Ca}^{2+}$-ATPase activity is partially inhibited by thapsigargin and is insensitive to 2,5-di-tert-bu- tyl-1,4-benzohydroquinone (DBHQ), whereas sarcoplasmic reticulum $\mathrm{Ca}^{2+}$-ATPase is inhibited by both inhibitors [109].

$N C X$. Unlike $\mathrm{Ca}^{2+}$-ATPase, $\mathrm{Na}^{+} / \mathrm{Ca}^{2+}$-exchanger (NCX) is a system of secondary active transport, which uses the $\mathrm{Na}^{+}$gradient (generated by $\mathrm{Na}^{+} / \mathrm{K}^{+}-$ ATPase) for $\mathrm{Ca}^{2+}$ transport against the concentration gradient [110]. Contrary to $\mathrm{Ca}^{2+}$-ATPase, NCX has low affinity to $\mathrm{Ca}^{2+}$ and high capacity, and is able to work in reverse mode under certain conditions (e.g., in heart, $\mathrm{NCX}$ provides $\mathrm{Ca}^{2+}$ influx into the myocyte and extrusion of $\mathrm{Na}^{+}$after membrane depolarization during systole as a result of voltage-dependent $\mathrm{Na}^{+}$ channels opening) [111, 112].

Generally, $\mathrm{Na}^{+} / \mathrm{Ca}^{2+}$ exchangers are associated with the functioning of excitable cells, however NCX expression either in the inner nuclear membrane solely or in both the plasma membrane and the nuclear envelope was found in many types of unexcitable cells, [37]. It is known that the nucleus is characterized by the presence of splice-variant of NCX1 isoform. It should be noted that nuclear NCX 
is characterized by atypical interaction with the gangliosides GM1, although the protein configuration is the same as that of the plasma membrane NCX [113]. Gangliosides, as components of the membrane environment, are involved in the regulation of $\mathrm{Na}^{+} / \mathrm{Ca}^{2+}$ exchanger activity, similarly to the function of inositol-4,5 bisphosphate (PIP2) in the plasma membrane NCX.

The localization of $\mathrm{Na}^{+} / \mathrm{K}^{+}$-ATPase and $\mathrm{Na}^{+} /$ $\mathrm{H}^{+}$exchanger in the inner nuclear membrane gives a reason to suggest that these systems are involved in the generation of primary transport gradient for the NCX operation in the nucleus. Thus, again on the example of the functioning of these transport systems, we can observe recapitulation of the plasma membrane features by the nuclear envelope.

\section{Relationship between cytoplasmic and intranuclear $\mathrm{Ca}^{2+}$}

The question of the mutual influence of cytoplasmic and nuclear $\mathrm{Ca}^{2+}$ levels, namely: whether an increase in $\mathrm{Ca}^{2+}$ concentration in the nucleoplasm is the only response to $\mathrm{Ca}^{2+}$ waves in the cytosol and the amplitudes of the $\mathrm{Ca}^{2+}$ signals in both compartments differ just slightly, or the increase in $\mathrm{Ca}^{2+}$ level in the nucleus occurs independently of cytosol event and plays a physiological role, is still open. In this aspect, it is important to note that $\mathrm{Ca}^{2+}$ diffuses in the cytosol at a lower rate than in the nucleus [37]. Therefore, $\mathrm{Ca}^{2+}$ influx through the voltage-dependent plasma membrane channels induces $\mathrm{Ca}^{2+}$ signals in the cytosol and increases only slightly (after a short delay) $\mathrm{Ca}^{2+}$ level in the nucleus. In contrast, $\mathrm{Ca}^{2+}$ released from the organelles near the nucleus is more likely to cause $\mathrm{Ca}^{2+}$ transients there than at a distance in the cytosol $[20,114]$. Confocal microscopy analysis of hepatocyte nuclei revealed that changes in the $\mathrm{Ca}^{2+}$ concentration in the cytosol induced rapid changes in the $\mathrm{Ca}^{2+}$ level in the nucleoplasm (measured using dextrans labeled with fluorescent calcium indicators: calcium-Green 1 and Fura 2) [116]. These results suggest that changes in cytoplasmic $\mathrm{Ca}^{2+}$ affect the $\mathrm{Ca}^{2+}$ level in the nucleus.

It is believed that the nucleus has an independent calcium signaling system, which can generate its own transients [67, 38]. Therefore, this organelle does not simply imitate the processes of changing the $\mathrm{Ca}^{2+}$ concentration in the cytosol but can initiate calcium signals. However, the relationship between cytoplasmic and nuclear calcium is obvious and can be observed in some cases: for example, the activa- tion of gene transcription is initiated by an increase in the concentration of cytosolic free $\mathrm{Ca}^{2+}$. Moreover, an increase in the cytosolic $\mathrm{Ca}^{2+}$ level triggers the NFAT activation: its dephosphorylation by $\mathrm{Ca}^{2+}-$ calmodulin-dependent phosphatase calcineurin results in exposure of the nuclear localization signal and translocation of NFAT as a complex with calcineurin to the nucleus. An increased $\mathrm{Ca}^{2+}$ level in the nucleus is necessary to maintain NFAT transcriptional activity since only under this condition calcineurin supports the active NFAT dephosphorylated state [37].

Interestingly, proteins that can be translocated into the nucleus and trigger the further stages of $\mathrm{Ca}^{2+}$ signaling in the nucleus can serve as a link between cytoplasmic and nuclear calcium. One such protein is calmodulin, a universal $\mathrm{Ca}^{2+}$-binding protein that functions in all eukaryotic cells. It is known that calmodulin is constitutively present in the nucleus, however additional calmodulin enters nucleus from the cytosol after cell stimulation (it was demonstrated on neurons). Since calmodulin molecule does not contain nuclear localization signal, it was assumed that it engages other carrier proteins containing NLS and translocates into the nucleus after an increase in cytosolic $\mathrm{Ca}^{2+}$ level [37]. In this case, nuclear $\mathrm{Ca}^{2+}$ transients are likely to be a response to a global increase in the $\mathrm{Ca}^{2+}$ level in the cytoplasm, while calmodulin in a complex with $\mathrm{Ca}^{2+}$ activates the nuclear $\mathrm{Ca}^{2+}$-calmodulin-dependent kinase involved in the transcription regulation through the mechanisms described in part III [30, 35, 38].

Several mechanisms are suggested for $\mathrm{Ca}^{2+}$ signals in the nucleus (Fig. 4) [38]. One of them postulates the existence of a connection between secondary messengers generated in the cytosol and $\mathrm{Ca}^{2+}$-signaling in the nucleus. Thus, $\mathrm{IP}_{3}$, a product of membrane phospholipid phosphatidylinositol-4,5bisphosphate PIP2 in the cytosol, diffuses to the nucleus, where it binds to type II IP ${ }_{3}$ receptors in the nucleoplasmic reticulum and induces the $\mathrm{Ca}^{2+}$ release into the nucleoplasm. However, the question arises: why $\mathrm{IP}_{3}$, which diffuses freely in the cytosol, targets precisely at the $\mathrm{IP}_{3}$ receptors in the nucleus, and not the $\mathrm{IP}_{3}$ receptors of endoplasmic reticulum, where the level of $\mathrm{IP}_{3}$ receptors is higher? The most likely reason is the different ligand-binding affinities of three types of $\mathrm{IP}_{3}$ receptors, namely: $\mathrm{IP}_{3} \mathrm{R} 2>\mathrm{IP}_{3} \mathrm{R} 1>\mathrm{IP}_{3} \mathrm{R} 3$ [116]. Therefore, if the cell nuclei express $\mathrm{IP}_{3} \mathrm{R} 2$ in a sufficient concentration, $\mathrm{Ca}^{2+}$-signaling in response to $\mathrm{IP}_{3}$ will begin in this compartment. 


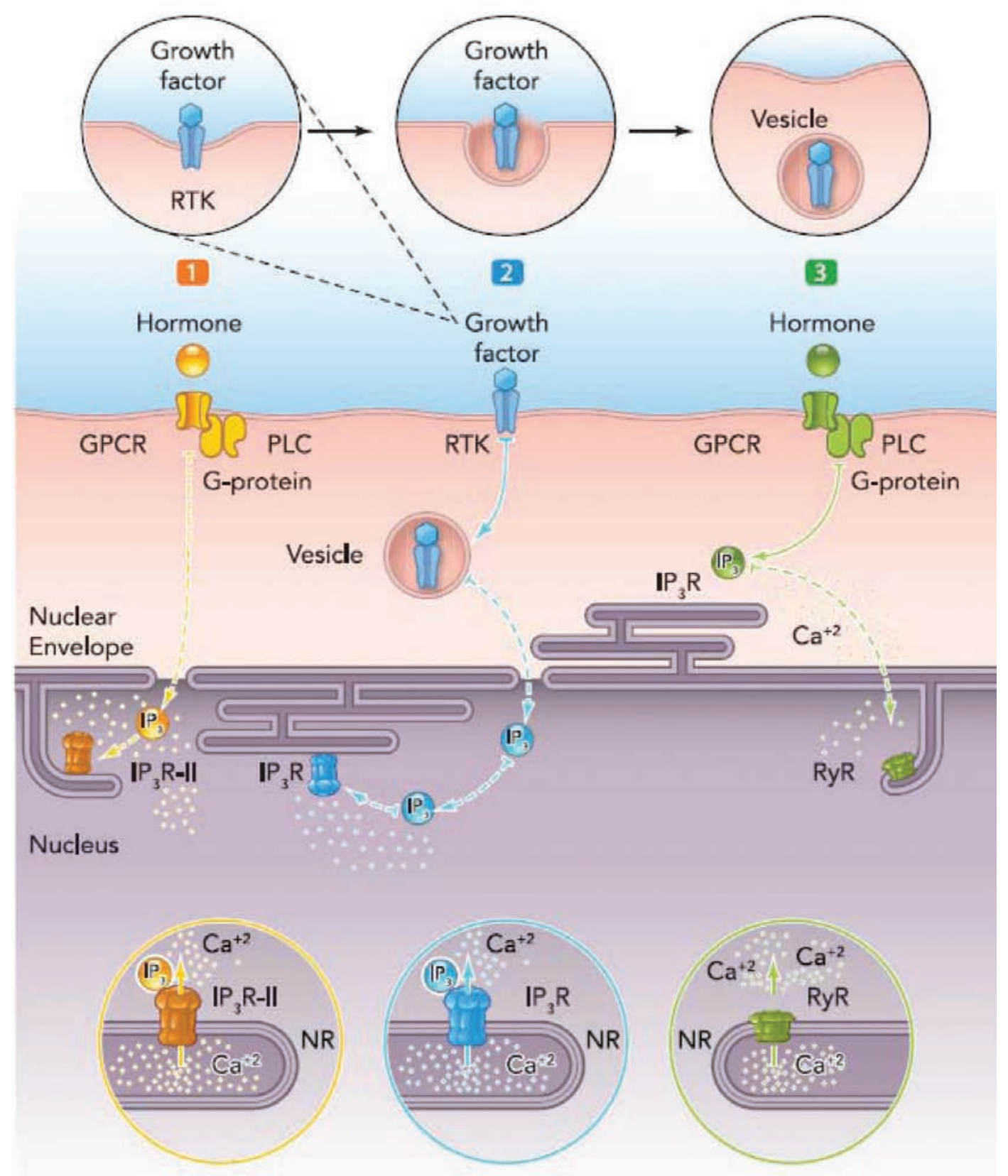

Fig. 4. Mechanisms for the $\mathrm{Ca}^{2+}$ concentrations increases in the nucleus [38]. 1 - the binding of an agonist to its receptor on the plasma membrane induces $I P_{3}$ generation by membrane phospholipase $C(P L C)$. IP $P_{3}$ diffuses in the cytosol and activates $I P_{3}$ receptors located in the nucleoplasmic reticulum; 2 - translocation of the growth factor-receptor tyrosine kinase (RTK) complex to the nucleus activates generation of the nuclear $I P_{3} ; 3$ - the binding of an agonist to its receptor on the plasma membrane induces $I P_{3}$ production with the involvement of membrane phospholipase $C$ (PLC). IP ${ }_{3}$ diffuses in the cytosol and activates $I P_{3}$ receptors located on the endoplasmic reticulum membrane. $\mathrm{Ca}^{2+}$ can diffuse from endoplasmic reticulum to the nucleus and activates $I P_{3}$ receptors located in the nucleoplasmic reticulum 
The second mechanism provides for an increase in the nuclear $\mathrm{Ca}^{2+}$ level as a consequence of independent from PM and cytosol $\mathrm{I}_{\mathrm{P} 3}$ generation in the nuclear membrane. The growth factor-receptor complex is translocated from the plasma membrane into the nucleus, where it stimulates hydrolysis of PIP2 to $\mathrm{IP}_{3}$ on the nuclear membrane. $\mathrm{IP}_{3}$, in turn, stimulates via $\mathrm{IP}_{3} \mathrm{R} 2$ the $\mathrm{Ca}^{2+}$ release into the nucleoplasm. Another mechanism suggests that $\mathrm{IP}_{3}$, generated as a result of activation of plasma membrane receptors, causes the release of $\mathrm{Ca}^{2+}$ from the $\mathrm{IP}_{3}$ receptors on the endoplasmic reticulum membrane. Endoplasmic reticulum calcium stimulates RyR in the nucleoplasmic reticulum and further increase in the $\mathrm{Ca}^{2+}$ concentration in the nucleoplasm (CICR$\mathrm{Ca}^{2+}$-induced $\mathrm{Ca}^{2+}$ release) [116, 38].

Furthermore, there is a mode suggesting that the nuclear $\mathrm{IP}_{3}$ receptors are stimulated by inositol triphosphate synthesized in membrane invaginations T-tubules located close to the nuclear envelope. This mechanism as a version of the first one may occur in skeletal muscles and cardiomyocytes, which are characterized by the presence of T-tubules [117]. Described mechanisms indicate that the nucleus can be either an independent generator of $\mathrm{Ca}^{2+}$ signaling or can act co-operatively with the events initiated in the cytosol.

\section{The nuclear transmembrane $\mathrm{Ca}^{2+}$ exchange disorders and "nuclear" pathologies}

To date, examples of "nuclear" pathologies (related to calcium signaling) have been established mainly for neurons in the brain and are often associated with the stimulation of extrasynaptic NMDA receptors (e-NMDARs) [55, 58]. The signal from synaptic NMDA receptors is known to cause $\mathrm{Ca}^{2+}$ transients in the cytosol and nucleus (through the activation of VGCCs in PM and $\mathrm{IP}_{3}$ channels in ER) and ultimately leads to the gene expression that provides neuroprotection and contributes to the neuron survival. In this aspect, e-NMDARs act as antagonists: their activation leads to an elevation in the $\mathrm{Ca}^{2+}$ concentration to a level at which some destructive processes resulting in excitotoxic neuronal death are triggered: the free radical generation, the mitochondrial inner membrane potential disruption and the activation of hydrolases [55]. These events are associated with CREB dephosphorylation and degradation, HDAC II accumulation in the nucleus and translocation of the proapoptotic factor $\mathrm{FOXO} 3 \mathrm{a}$ to the nucleus [35]. However, the question still remains how the nucleus distinguishes between $\mathrm{Ca}^{2+}$ transients caused by the stimulation of synaptic and extrasynaptic NMDA receptors.

Some neurodegenerative disorders, in particular, Alzheimer's and Huntington's diseases, as well as hypoxic conditions and strokes, are associated with an increased level of e-NMDARs activation and abnormalities in $\mathrm{Ca}^{2+}$-signaling in neuronal nuclei [118, 119]. Interestingly, increased activation of e-NMDARs upon Alzheimer's disease can be a consequence of the $\beta$-amyloid-induced excessive glutamate release from glial cells. The activation of e-NMDARs, in turn, leads to the $\beta$-amyloid formation, neuronal death, and synapse loss, and such vicious circle results in impaired synaptic plasticity and brain cognitive dysfunction [58, 63]. This kind of nuclear $\mathrm{Ca}^{2+}$ signaling dysfunctions was called "nuclear calciopathy" [35].

In addition, changes in nuclear $\mathrm{Ca}^{2+}$ concentration cause cardiomyocyte hypertrophy: both physiological (regulated by insulin-like growth factor IGF-1) and pathological (induced by endothelin 1 (ET-1)) [64]. Autocrine and paracrine factors, that act during stress and induce cardiac muscle hypertrophy, activate the phosphatidylinositol cascade, which results in an increase in the intracellular $\mathrm{Ca}^{2+}$ concentration [65]. Arantes L.A.M. et al. demonstrated that the increase in nuclear, not cytosolic, $\mathrm{IP}_{3}$ level is a key stage in the development of cardiomyocyte hypertrophy and inducer of the activation of nuclear $\mathrm{Ca}^{2+}$-calmodulin-dependent kinase II, which, in turn, induces histone deacetylase export from the nucleus (through phosphorylation) and gene expression involved in increasing the cardiomyocyte size. To understand the role of nuclear $\mathrm{IP}_{3}$ and nuclear $\mathrm{Ca}^{2+}$ in these processes, a vector containing the $\mathrm{IP}_{3} \mathrm{R}$ ligand-binding domain bound to a nuclear localization signal, and serving as a buffer for nuclear $\mathrm{IP}_{3}$ was used. A decrease in the level of free nuclear $\mathrm{IP}_{3}{ }_{3}$ inhibited hypertrophy processes [64].

The phenomenon of "nuclear calciopathy" can certainly occur under other pathological conditions. However, it should be established in which cases the disorder of transmembrane calcium metabolism and calcium signaling in the nucleus is one of the prerequisites of pathology and has a therapeutic effect.

Thus, the nucleus is an essential component of the $\mathrm{Ca}^{2+}$ accumulation system in the cell. The specificity of the nucleus as a central player in the realization of genetic information defines the range of particular functions of nuclear calcium. The 
functioning of its own systems involved in the $\mathrm{Ca}^{2+}$ transport $\left(\mathrm{IP}_{3}-\right.$, $\mathrm{IP}_{4}$-receptors, ryanodine receptors, NAADP receptors, $\mathrm{Ca}^{2+}$-ATPase, $\mathrm{Na}^{+} / \mathrm{Ca}^{2+}$-exchanger) indicates that the nuclear envelope can autonomously generate calcium signals. However, detailed mechanisms for normalizing the $\mathrm{Ca}^{2+}$ level in the nucleoplasm remain to be clarified. In addition, the mechanism for increasing nuclear $\mathrm{Ca}^{2+}$ is still an open question.

The work was performed with the financial support of grants: state registration No: 0115U003638, 0115U003639, 0117U006348.

\section{ШЛЯХИ ТА МЕХАНІЗМИ ТРАНСМЕМБРАННОГО ОБМІНУ ІОНІВ Са В КЛІТИННОМУ ЯДРІ}

\section{T. О. Векліч, Ю. В. Ніконішина, \\ C. О. Костерін}

Інститут біохімії ім. О. В. Палладіна НАН України, Київ; e-mail: veklich@biochem.kiev.ua

Функції $\mathrm{Ca}^{2+}$ в клітинному ядрі різноманітні (регуляція транскрипції генів, проникності ядерних пор, активація ензимів, залучених в апоптоз) та визначають долю будь-якого типу клітини. Тому шляхи надходження $\mathrm{Ca}^{2+}$ до ядра, питання взаємозв'язку цитозольних та ядерних кальцієвих сигналів, накопичення та виходу $\mathrm{Ca}^{2+}$ з ядерних депо та їхня подальша роль являють неабиякий інтерес. В огляді узагальнено дані літератури і результати власних досліджень щодо особливостей транспорту $\mathrm{Ca}^{2+}$ в клітині, зокрема зосереджено увагу на транспортних системах та загальних механізмах обміну цього вторинного месенджера в центральній органелі клітини - ядрі. Також розглянуто загальну структуру клітинного ядра, транспортери ядерної оболонки, функції $\mathrm{Ca}^{2+}$ в ядрі та порушення кальцієвого сигналінгу в ядрі.

К л ю ч о в і с л о ва: ядро, нуклеоплазма, ядерна оболонка, ядерні транспортери, кальцієвий сигналінг.

\section{ПУТИ И МЕХАНИЗМЫ ТРАНСМЕМБРАННОГО ОБМЕНА ИОНОВ Са В КЛЕТОЧНОМ ЯДРЕ}

\author{
Т. А. Веклич, Ю. В. Никонишина, \\ C. А. Костерин
}
Институт биохимии им. А. В. Палладина НАН Украины, Киев; e-mail: veklich@biochem.kiev.ua

Функции $\mathrm{Ca}^{2+}$ в клеточном ядре разнообразны (регуляция транскрипции генов, проницаемости ядерных пор, активация энзимов, вовлеченных в апоптоз) и определяют судьбу любого типа клетки. Поэтому пути поступления $\mathrm{Ca}^{2+}$ в ядро, вопросы взаимосвязи цитозольных и ядерных кальциевых сигналов, накопления и выхода $\mathrm{Ca}^{2+}$ из ядерных депо и их дальнейшая роль представляют большой интерес. В обзоре обобщены данные литературы и результаты собственных исследований об особенностях транспорта $\mathrm{Ca}^{2+}$ в клетке, в частности сосредоточено внимание на транспортных системах и общих механизмах обмена этого вторичного мессенджера в центральной органелле клетки ядре. Также рассмотрены общая структура клеточного ядра, транспортеры ядерной оболочки, функции $\mathrm{Ca}^{2+}$ в ядре и нарушения кальциевого сигналинга в ядре.

К л ю ч е вы е с л о в а: ядро, нуклеоплазма, ядерная оболочка, ядерные транспортеры, кальциевый сигналинг.

\section{References}

1. Kosterin SO, Babich LG, Shlykov SG, Danylovych IuV, Veklich TO, Mazur YuYu. Biochemical properties and regulation of smooth muscle cell $\mathrm{Ca}^{2+}$-transporting systems. K.: Science opinion, 2016. 210 p.

2. Babich LG. Membrane mechanisms whereby $\left[\mathrm{Ca}^{2+}\right]_{\mathrm{i}}$ is regulated in smooth muscle cells. I. Energy-dependent systems of $\mathrm{Ca}^{2+}$ transport in smooth muscles. Ukr Biokhim Zhurn. 1999; 71(5): 10-22. (In Ukrainian).

3. Kosterin SO. Calcium transport in smooth muscles. K.: Science opinion, 1990. 216 p. 
4. Veklich TO, Mazur YuYu, Kosterin SO. $\mathrm{Mg}^{2+}$,ATP-dependent plasma membrane calcium pump of smooth muscle cells. I. Structural organization and properties. Ukr Biochem J. 2015; 87(1): 5-20. (In Ukrainian).

5. Clapham DE. Calcium signaling. Cell. 1995; 80(2): 259-268.

6. $\mathrm{Pu} \mathrm{Y}$, Chang DC. Cytosolic $\mathrm{Ca}(2+)$ signal is involved in regulating UV-induced apoptosis in hela cells. Biochem Biophys Res Commun. 2001; 282(1): 84-89.

7. Somlyo AP, Somlyo AV. Signal transduction by G-proteins, rho-kinase and protein phosphatase to smooth muscle and non-muscle myosin II. J Physiol. 2000; 522(2): 177-185.

8. Kosterin SA, Bratkova NF, Babich LG, Shinlova OP, Slinchenko NN, Shlykov SG, Zimina BP, Rovenets NA, Velkich TA. Effect of inhibitors of energy-dependent $\mathrm{Ca}^{2+}$ transporting systems on calcium pumps of a smooth muscle cell. Ukr Biokhim Zhurn. 1996; 68(6): 50-61. (In Russian).

9. Rizzuto R, Pinton P, Carrington W, Fay FS, Fogarty KE, Lifshitz LM, Tuft RA, Pozzan T. Close contacts with the endoplasmic reticulum as determinants of mitochondrial $\mathrm{Ca}^{2+}$ responses. Science. 1998; 280(5370): 1763-1766.

10. Sanborn BM. Hormonal signaling and signal pathway crosstalk in the control of myometrial calcium dynamics. Semin Cell Dev Biol. 2007; 18(3): 305-314.

11. Levitsky DO. Calcium and biological membranes. M.: Vyschaya shkola publ., 1990. 124 p. (In Russian).

12. Berchtold MW, Brinkmeier H, Müntener M. Calcium ion in skeletal muscle: its crucial role for muscle function, plasticity, and disease. Physiol Rev. 2000; 80(3): 1215-1265.

13. Marshall WJ. Clinical Biochemistry. Moscow: Publ. BINOM, 2015. 408 p. (In Russian).

14. Babich LG, Shlykov SG, Strutinskaia NA, Kosterin SA. Properties of the smooth muscle cell endoplasmic reticulum calcium pump. Ukr Biokhim Zhurn. 1999; 71(2):20-27. (In Russian).

15. Veklich TO, Kosterin SO, Shynlova OP. Cationic specificity of a $\mathrm{Ca}^{2+}$-accumulating system in smooth muscle cell mitochondria. Ukr Biokhim Zhurn. 2002; 74(1): 42-48. (In Ukrainian).

16. Kosterin SA, Babich LG, Shlykov SG, Rovenets NA. $\mathrm{Mg}^{2+}$,ATP-dependent transport of $\mathrm{Ca}^{2+}$ in the endoplasmic reticulum of myometrial cells. Biokhimiia. 1996; 61(1): 73-81. (In Russian).
17. Shinlova OP, Kosterin SA, Veklich TA. Ruthenium red inhibits energy-dependent and passive $\mathrm{Ca}^{2+}$ transport in permeabilized smooth muscle cells. Biokhimiia. 1996; 61(8): 1440-1447. (In Russian).

18. Brini M, Murgia M, Pasti L, Picard D, Pozzan T, Rizzuto R. Nuclear $\mathrm{Ca}^{2+}$ concentration measured with specifically targeted recombinant aequorin. EMBO J. 1993; 12(12): 4813-4819.

19. Matyshevska OP, Borisov SI, Grebinyk DM. Particulars on the regulation of $\mathrm{Ca}^{2+}$ in the cell nucleus. Ukr Biokhim Zhurn. 2002; 74(5): 5-11. (In Ukrainian).

20. Malviya AN, Rogue PJ. "Tell me where is calcium bred": clarifying the roles of nuclear calcium. Cell. 1998; 92(1):7-23.

21. LaFerla FM. Calcium dyshomeostasis and intracellular signalling in Alzheimer's disease. Nat Rev Neurosci. 2002; 3(11): 862-872.

22. Ivannikov MV, Macleod GT. Mitochondrial free $\mathrm{Ca}^{2+}$ levels and their effects on energy metabolism in Drosophila motor nerve terminals. Biophys $J$. 2013; 104(11): 2353-2361.

23. Contreras L, Drago I, Zampese E, Pozzan T. Mitochondria: the calcium connection. Biochim Biophys Acta. 2010; 1797(6-7): 607-618.

24. White PJ, Broadley MR. Calcium in plants. Ann Bot. 2003; 92(4): 487-511.

25. Kondratev D, Gallitelli MF. Increments in the concentrations of sodium and calcium in cell compartments of stretched mouse ventricular myocytes. Cell Calcium. 2003; 34(2): 193-203.

26. Badminton MN, Campbell AK, Rembold CM. Differential regulation of nuclear and cytosolic $\mathrm{Ca}^{2+}$ in HeLa cells. J Biol Chem. 1996; 271(49): 31210-31214.

27. Petersen OH, Gerasimenko OV, Gerasimenko JV, Mogami H, Tepikin AV. The calcium store in the nuclear envelope. Cell Calcium. 1998; 23(2-3): 87-90.

28. Badminton MN, Kendall JM, Sala-Newby G, Campbell AK. Nucleoplasmin-targeted aequorin provides evidence for a nuclear calcium barrier. Exp Cell Res. 1995; 216(1): 236-243.

29. Badminton MN, Kendall JM, Rembold CM, Campbell AK. Current evidence suggests independent regulation of nuclear calcium. Cell Calcium. 1998; 23(2-3): 79-86.

30. Papadia S, Stevenson P, Hardingham NR, Bading $\mathrm{H}$, Hardingham GE. Nuclear $\mathrm{Ca}^{2+}$ and the cAMP response element-binding protein 
family mediate a late phase of activity-dependent neuroprotection. J Neurosci. 2005; 25(17): 42794287.

31. Hardingham GE, Chawla S, Cruzalegui FH, Bading $\mathrm{H}$. Control of recruitment and transcription-activating function of CBP determines gene regulation by NMDA receptors and L-type calcium channels. Neuron. 1999; 22(4): 789-798.

32. Linseman DA, Bartley CM, Le SS, Laessig TA, Bouchard RJ, Meintzer MK, $\mathrm{Li}$ M, Heidenreich KA. Inactivation of the myocyte enhancer factor-2 repressor histone deacetylase- 5 by endogenous $\mathrm{Ca}^{2+} /$ calmodulindependent kinase II promotes depolarizationmediated cerebellar granule neuron survival. $J$ Biol Chem. 200; 278(42): 41472-41481.

33. McKenzie GJ, Stevenson P, Ward G, Papadia S, Bading H, Chawla S, Privalsky M, Hardingham GE. Nuclear $\mathrm{Ca}^{2+}$ and CaM kinase IV specify hormonal- and Notch-responsiveness. J Neurochem. 2005; 93(1): 171-185.

34. Limbäck-Stokin K, Korzus E, NagaokaYasuda R, Mayford M. Nuclear calcium/ calmodulin regulates memory consolidation. J Neurosci. 2004; 24(48): 10858-10867.

35. Bading $H$. Nuclear calcium signalling in the regulation of brain function. Nat Rev Neurosci. 2013; 14(9): 593-608.

36. Hayer SN, Bading H. Nuclear calcium signaling induces expression of the synaptic organizers Lrrtm1 and Lrrtm2. J Biol Chem. 2015; 290(9): 5523-5532.

37. Bootman MD, Fearnley C, Smyrnias I, MacDonald F, Roderick HL. An update on nuclear calcium signalling. J Cell Sci. 2009; 122(Pt 14): 2337-2350.

38. Oliveira AG, Guimarães ES, Andrade LM, Menezes GB, Fatima Leite M. Decoding calcium signaling across the nucleus. Physiology (Bethesda). 2014; 29(5): 361-368.

39. Fedirko N, Gerasimenko JV, Tepikin AV, Gerasimenko OV. Regulation of early response genes in pancreatic acinar cells: external calcium and nuclear calcium signalling aspects. Acta Physiol (Oxf). 2009; 195(1): 51-60.

40. Greber UF, Senior A, Gerace L. A major glycoprotein of the nuclear pore complex is a membrane-spanning polypeptide with a large lumenal domain and a small cytoplasmic tail. EMBO J. 1990; 9(5): 1495-1502.
41. Starr CM, Hanover JA. Structure and Function of Nuclear Pore Glycoproteines. Nuclear Trafficking. Ed. Feldherr CM. 1992; 7: 175-201.

42. Wozniak RW, BlobelG. Thesingletransmembrane segment of gp210 is sufficient for sorting to the pore membrane domain of the nuclear envelope. J Cell Biol. 1992; 119(6): 1441-1449.

43. Perez-Terzic C, Jaconi M, Stehno-Bittel L. Measurement of intracellular calcium concentration using confocal microscopy. Methods Mol Biol. 1999; 114: 75-91.

44. Higazi DR, Fearnley CJ, Drawnel FM, Talasila A, Corps EM, Ritter O, McDonald F, Mikoshiba K, Bootman MD, Roderick HL. Endothelin-1-stimulated InsP3-induced $\mathrm{Ca}^{2+}$ release is a nexus for hypertrophic signaling in cardiac myocytes. Mol Cell. 2009; 33(4): 472482.

45. Nicotera P, Zhivotovsky B, Orrenius S. Nuclear calcium transport and the role of calcium in apoptosis. Cell Calcium. 1994; 16(4): 279-288.

46. Cardoso MC. Law and order in the nucleus. Zellbiologie Aktuell. 2003; 29(3): 8-10.

47. Dundr M, Misteli T. Functional architecture in the cell nucleus. Biochem J. 2001; 356(Pt 2): 297310.

48. Pederson T. The Nucleus by Tom Misteli and David L. Spector, eds. (2011) CSHL Press, New York. FASEB J. 2012; 26(1): 9-10.

49. Monneron A, Bernhard W. Fine structural organization of the interphase nucleus in some mammalian cells. J Ultrastruct Res. 1969;27(3): 266-288.

50. Montgomery TH. Comparative cytological studies, with especial regard to the morphology of the nucleolus. J Morphol. 1898; 15(2): 265582.

51. Gavrilov AA, Razin SV. Compartmentalization of the cell nucleus and spatial organization of the genome. Mol Biol. 2015; 49(1): 21-39.

52. Gonzalez-Melendi P, Beven A, Boudonck K, Abranches R, Wells B, Dolan L, Shaw P. The nucleus: a highly organized but dynamic structure. J Microsc. 2000; 198(Pt 3): 199-207.

53. Hancock R. Internal organisation of the nucleus: assembly of compartments by macromolecular crowding and the nuclear matrix model. Biol Cell. 2004; 96(8): 595-601.

54. Lamond AI, Earnshaw WC. Structure and function in the nucleus. Science. 1998; 280(5653): 547-553. 
55. Hardingham GE, Bading H. Synaptic versus extrasynaptic NMDA receptor signalling: implications for neurodegenerative disorders. Nat Rev Neurosci. 2010; 11(10): 682-696.

56. Tsai RY, McKay RD. A multistep, GTP-driven mechanism controlling the dynamic cycling of nucleostemin. J Cell Biol. 2005; 168(2): 179-184.

57=82. Matzke AJ, Weiger TM, Matzke M. Ion channels at the nucleus: electrophysiology meets the genome. Mol Plant. 2010; 3(4): 642-652.

58. Bordji K, Becerril-Ortega J, Nicole O, Buisson A. Activation of extrasynaptic, but not synaptic, NMDA receptors modifies amyloid precursor protein expression pattern and increases amyloid- $\beta$ production. $J$ Neurosci. 2010; 30(47): 15927-15942.

59. Dingwall C, Laskey R. The nuclear membrane. Science. 1992; 258(5084): 942-947.

60. Akey CW. Interactions and structure of the nuclear pore complex revealed by cryo-electron microscopy. J Cell Biol. 1989; 109(3): 955-970.

[61. Hinshaw JE, Carragher BO, Milligan RA. Architecture and design of the nuclear pore complex. Cell. 1992; 69(7): 1133-1141.

62. Clever J, Yamada M, Kasamatsu H. Import of simian virus 40 virions through nuclear pore complexes. Proc Natl Acad Sci USA. 1991; 88(16): 7333-7337.

63. Li S, Jin M, Koeglsperger T, Shepardson NE, Shankar GM, Selkoe DJ. Soluble A $\beta$ oligomers inhibit long-term potentiation through a mechanism involving excessive activation of extrasynaptic NR2B-containing NMDA receptors. J Neurosci. 2011; 31(18): 6627-6638.

64. Arantes LA, Aguiar CJ, Amaya MJ, Figueiró NC, Andrade LM, Rocha-Resende C, Resende RR, Franchini KG, Guatimosim S, Leite MF. Nuclear inositol 1,4,5-trisphosphate is a necessary and conserved signal for the induction of both pathological and physiological cardiomyocyte hypertrophy. J Mol Cell Cardiol. 2012; 53(4): 475-486.

65. Heineke J, Molkentin JD. Regulation of cardiac hypertrophy by intracellular signalling pathways. Nat Rev Mol Cell Biol. 2006; 7(8): 589-600.

66. Matzke M, Aufsatz W, Gregor W, van Der Winden J, Papp I, Matzke AJ. Ion transporters in the nucleus? Plant Physiol. 2001; 127(1): 10-13.

67. Gerasimenko O, Gerasimenko J. New aspects of nuclear calcium signalling. J Cell Sci. 2004; 117(Pt 15): 3087-3094.
68. Macara IG. Transport into and out of the nucleus. Microbiol Mol Biol Rev. 2001; 65(4): 570-594.

69. Wente SR, Rout MP. The nuclear pore complex and nuclear transport. Cold Spring Harb Perspect Biol. 2010; 2(10): a000562.

70. Mekhail K, Moazed D. The nuclear envelope in genome organization, expression and stability. Nat Rev Mol Cell Biol. 2010; 11(5): 317-328.

71. Greber UF, Gerace L. Depletion of calcium from the lumen of endoplasmic reticulum reversibly inhibits passive diffusion and signal-mediated transport into the nucleus. J Cell Biol. 1995; 128(1-2): 5-14.

72. Hodel MR, Corbett AH, Hodel AE. Dissection of a nuclear localization signal. $\mathrm{J}$ Biol Chem. 2001; 276(2): 1317-1325.

73. Franco-Obregón A, Wang HW, Clapham DE. Distinct ion channel classes are expressed on the outer nuclear envelope of T- and B-lymphocyte cell lines. Biophys J. 2000; 79(1): 202-214.

74. Jans DA, Xiao CY, Lam MH. Nuclear targeting signal recognition: a key control point in nuclear transport? Bioessays. 2000; 22(6): 532-544.

75. Charpentier M, Vaz Martins T, Granqvist E, Oldroyd GE, Morris RJ. The role of DMI1 in establishing $\mathrm{Ca}(2+)$ oscillations in legume symbioses. Plant Signal Behav. 2013; 8(2): e22894.

76. Venkateshwaran M, Cosme A, Han L, Banba M, Satyshur KA, Schleiff E, Parniske M, ImaizumiAnraku H, Ané JM. The recent evolution of a symbiotic ion channel in the legume family altered ion conductance and improved functionality in calcium signaling. Plant Cell. 2012; 24(6): 2528-2545.

77. Atkinson L, Milligan CJ, Buckley NJ, Deuchars J. An ATP-gated ion channel at the cell nucleus. Nature. 2002; 420(6911): 42.

78. Surprenant A, Rassendren F, Kawashima E, North RA, Buell G. The cytolytic P2Z receptor for extracellular ATP identified as a P2X receptor (P2X7). Science. 1996; 272(5262): 735-738.

79. Stonehouse AH, Grubb BD, Pringle JH, Norman RI, Stanfield PR, Brammar WJ. Nuclear immunostaining in rat neuronal cells using two anti-Kir2.2 ion channel polyclonal antibodies. J Mol Neurosci. 2003; 20(2): 189-194.

80. Santos RM, Rosario LM, Nadal A, GarciaSancho J, Soria B, Valdeolmillos M. Widespread synchronous $\left[\mathrm{Ca}^{2+}\right]_{i}$ oscillations due to bursting electrical activity in single pancreatic islets. Pflugers Arch. 1991; 418(4): 417-422. 
81. Quesada I, Rovira JM, Martin F, Roche E, Nadal A, Soria B. Nuclear KATP channels trigger nuclear $\mathrm{Ca}(2+)$ transients that modulate nuclear function. Proc Natl Acad Sci USA. 2002; 99(14): 9544-9549.

82. Kondor-Koch C, Riedel N, Valentin R, Fasold H, Fischer H. Characterization of an ATPase on the inside of rat-liver nuclear envelopes by affinity labeling. Eur J Biochem. 1982; 127(2): 285-289.

83. Garner MH. Na,K-ATPase in the nuclear envelope regulates $\mathrm{Na}^{+}: \mathrm{K}^{+}$gradients in hepatocyte nuclei. J Membr Biol. 2002; 187(2): 97-115.

84. Galva C, Artigas P, Gatto C. Nuclear $\mathrm{Na}^{+} / \mathrm{K}^{+}-$ ATPase plays an active role in nucleoplasmic $\mathrm{Ca}^{2+}$ homeostasis. J Cell Sci. 2012; 125(Pt 24): 6137-6147.

85. Humbert JP, Matter N, Artault JC, Köppler P, Malviya AN. Inositol 1,4,5-trisphosphate receptor is located to the inner nuclear membrane vindicating regulation of nuclear calcium signaling by inositol 1,4,5-trisphosphate. Discrete distribution of inositol phosphate receptors to inner and outer nuclear membranes. J Biol Chem. 1996; 271(1): 478-485.

86. Xie X, Wu G, Ledeen RW. C6 cells express a sodium-calcium exchanger/GM1 complex in the nuclear envelope but have no exchanger in the plasma membrane: comparison to astrocytes. J Neurosci Res. 2004; 76(3): 363-375.

87. Santos JM, Martínez-Zaguilán R, Facanha AR, Hussain F, Sennoune SR. Vacuolar $\mathrm{H}^{+}$-ATPase in the nuclear membranes regulates nucleocytosolic proton gradients. Am J Physiol Cell Physiol. 2016; 311(4): C547-C558.

88. Cancela JM, Van Coppenolle F, Galione A, Tepikin AV, Petersen $\mathrm{OH}$. Transformation of local $\mathrm{Ca}^{2+}$ spikes to global $\mathrm{Ca}^{2+}$ transients: the combinatorial roles of multiple $\mathrm{Ca}^{2+}$ releasing messengers. EMBO J. 2002; 21(5): 909-919.

89. Malviya AN, Rogue $\mathrm{P}$, Vincendon G. Stereospecific inositol 1,4,5-[32P]trisphosphate binding to isolated rat liver nuclei: evidence for inositol trisphosphate receptor-mediated calcium release from the nucleus. Proc Natl Acad Sci USA. 1990; 87(23): 9270-9274.

90. Laporte R, Hui A, Laher I. Pharmacological modulation of sarcoplasmic reticulum function in smooth muscle. Pharmacol Rev. 2004; 56(4): 439-513.

91. Krutetskaya Z.I. Mechanisms of $\mathrm{Ca}^{2+}$ signaling in cells. Mechanisms of Intracellular Signaling:
Monograph. St. Petersburg University Press, St. Petersburg, 2003; 209 p. (In Russian).

92. Rossi D, Sorrentino V. Molecular genetics of ryanodine receptors $\mathrm{Ca}^{2+}$-release channels. Cell Calcium. 2002; 32(5-6): 307-319.

93. Zhu MX, Ma J, Parrington J, Galione A, Evans AM. TPCs: Endolysosomal channels for $\mathrm{Ca}^{2+}$ mobilization from acidic organelles triggered by NAADP. FEBS Lett. 2010; 584(10): 1966-1974.

94. Moccia F, Berra-Romani R, Tanzi F. Update on vascular endothelial $\mathrm{Ca}(2+)$ signalling: A tale of ion channels, pumps and transporters. World $J$ Biol Chem. 2012; 3(7): 127-158.

95. Patel S, Marchant JS, Brailoiu E. Twopore channels: Regulation by NAADP and customized roles in triggering calcium signals. Cell Calcium. 2010; 47(6): 480-490.

96. Galione A, Petersen OH. The NAADP receptor: new receptors or new regulation? Mol Interv. 2005; 5(2): 73-79.

97. Gerasimenko JV, Maruyama Y, Yano K, Dolman NJ, Tepikin AV, Petersen OH, Gerasimenko OV. NAADP mobilizes $\mathrm{Ca}^{2+}$ from a thapsigargin-sensitive store in the nuclear envelope by activating ryanodine receptors. J Cell Biol. 2003; 163(2): 271-282.

98. Koppler P, Matter N, Malviya AN. Evidence for stereospecific inositol 1,3,4,5-[3H] tetrakisphosphate binding sites on rat liver nuclei. Delineating inositol 1,3,4,5-tetrakisphosphate interaction in nuclear calcium signaling process. J Biol Chem. 1993; 268(35): 26248-26252.

99. Santella L, Carafoli E. Calcium signaling in the cell nucleus. FASEB J. 1997; 11(13): 1091-1109.

100. Alcázar-Román AR1, Wente SR. Inositol polyphosphates: a new frontier for regulating gene expression. Chromosoma. 2008;117(1):113.

101. Wu M, Chong LS, Perlman DH, Resnick AC, Fiedler D. Inositol polyphosphates intersect with signaling and metabolic networks via two distinct mechanisms. Proc Natl Acad Sci USA. 2016; 113(44): E6757-E6765.

102. Gerasimenko OV, Gerasimenko JV, Tepikin AV, Petersen $\mathrm{OH}$. Calcium transport pathways in the nucleus. Pflugers Arch. 1996; 432(1): 1-6.

103. Nicotera P, McConkey DJ, Jones DP, Orrenius S. ATP stimulates $\mathrm{Ca}^{2+}$ uptake and increases the free $\mathrm{Ca}^{2+}$ concentration in isolated rat liver nuclei. Proc Natl Acad Sci USA. 1989; 86(2): 453-457. 
104. Gerasimenko OV, Gerasimenko JV, Tepikin AV, Petersen $\mathrm{OH}$. ATP-dependent accumulation and inositol trisphosphate- or cyclic ADPribose-mediated release of $\mathrm{Ca}^{2+}$ from the nuclear envelope. Cell. 1995; 80(3): 439-444.

105. Adebanjo OA, Biswas G, Moonga BS, Anandatheerthavarada HK, Sun L, Bevis PJ, Sodam BR, Lai FA, Avadhani NG, Zaidi M. Novel biochemical and functional insights into nuclear $\mathrm{Ca}(2+)$ transport through IP(3)Rs and RyRs in osteoblasts. Am J Physiol Renal Physiol. 2000; 278(5): F784-F791.

106. Mishra OP, Delivoria-Papadopoulos M. Nitric oxide-mediated $\mathrm{Ca}++$-influx in neuronal nuclei and cortical synaptosomes of normoxic and hypoxic newborn piglets. Neurosci Lett. 2002; 318(2): 93-97.

107. Shahin V, Danker T, Enss K, Ossig R, Oberleithner $\mathrm{H}$. Evidence for $\mathrm{Ca}^{2+}$ - and ATPsensitive peripheral channels in nuclear pore complexes. FASEB J. 2001 Sep;15(11):1895901.

108. Borysov SI, Grebinyk DM, Matyshevska OP. $\mathrm{Ca}^{2+}$-ATPase activity and ATP-dependent accumulation of $\mathrm{Ca}^{2+}$ in spleen lymphocytes nuclei of X-irradiated animals. Taras Shevchenko National University Press. Biology. 2001; 33: 20-22. (In Ukrainian).

109. Nicotera P, Rossi AD. Nuclear $\mathrm{Ca}^{2+}$ : physiological regulation and role in apoptosis. Mol Cell Biochem. 1994; 135(1): 89-98.

110. Noble D, Herchuelz A. Role of $\mathrm{Na} / \mathrm{Ca}$ exchange and the plasma membrane $\mathrm{Ca}^{2+}$-ATPase in cell function. Conference on $\mathrm{Na} / \mathrm{Ca}$ exchange. EMBO Rep. 2007; 8(3): 228-232.

111. Lytton $\mathrm{J} . \mathrm{Na}^{+} / \mathrm{Ca}^{2+}$ exchangers: three mammalian gene families control $\mathrm{Ca}^{2+}$ transport. Biochem J. 2007; 406: 365-382.
112. Brini M, Carafoli E. The plasma membrane $\mathrm{Ca}^{2+}$ ATPase and the plasma membrane sodium calcium exchanger cooperate in the regulation of cell calcium. Cold Spring Harb Perspect Biol. 2011; 3(2). pii: a004168.

113. Ledeen RW, Wu G. Nuclear sphingolipids: metabolism and signaling. J Lipid Res. 2008; 49(6): 1176-1186.

114. Lipp P, Thomas D, Berridge MJ, Bootman MD. Nuclear calcium signalling by individual cytoplasmic calcium puffs. EMBO J. 1997;16(23): 7166-7173.

115. Iwai M, Michikawa T, Bosanac I, Ikura M, Mikoshiba K. Molecular basis of the isoformspecific ligand-binding affinity of inositol 1,4,5-trisphosphate receptors. J Biol Chem. 2007; 282(17): 12755-12764.

116. Rodrigues MA, Gomes DA, Andrade VA, Leite MF, Nathanson MH. Insulin induces calcium signals in the nucleus of rat hepatocytes. Hepatology. 2008; 48(5): 1621-1631.

117. Ibarra C, Vicencio JM, Estrada M, Lin Y, Rocco P, Rebellato P, Munoz JP, GarciaPrieto J, Quest AF, Chiong M, Davidson SM, Bulatovic I, Grinnemo KH, Larsson O, Szabadkai G, Uhlén $P$, Jaimovich E, Lavandero S. Local control of nuclear calcium signaling in cardiac myocytes by perinuclear microdomains of sarcolemmal insulin-like growth factor 1 receptors. Circ Res. 2013; 112(2): 236-245.

118. Lipton SA. Failures and successes of NMDA receptor antagonists: molecular basis for the use of open-channel blockers like memantine in the treatment of acute and chronic neurologic insults. NeuroRx. 2004; 1(1): 101-110.

119. Bading $H$. Therapeutic targeting of the pathological triad of extrasynaptic NMDA receptor signaling in neurodegenerations. J Exp Med. 2017; 214(3): 569-578.

Received 26.01.2018 